Received 03.08.2015 Reviewed 20.08.2015 Accepted 25.08.2015

A - study design

B - data collection

C - statistical analysis

D - data interpretation

$\mathbf{E}$ - manuscript preparation

F - literature search

\section{Implications of spatial scale on climate change assessments}

\footnotetext{
1) Arba Minch University, Department of Water Resource and Irrigation Engineering, Arba Minch, P.O. Box 21, Ethiopia; e-mail: pingalesm@gmail.com

2) McGill University, Faculty of Agricultural and Environmental Sciences, Department of Bioresource Engineering, Quebec, Canada, H9X 3V9; e-mail: jan.adamowski@mcgill.ca

${ }^{3)}$ Malaviya National Institute of Technology, Department of Civil Engineering, Jaipur, Rajasthan, India; e-mail: mahesh.mnit @ gmail.com

4) Indian Institute of Technology Roorkee, Department of Water Resource Development and Management, Roorkee 247667 (UA), India; e-mail: kharefwt@gmail.com
}

For citation: Pingale S., Adamowski J., Jat M., Khare D. 2015. Implications of spatial scale on climate change assessments. Journal of Water and Land Development. No. 26 p. 37-56.

\begin{abstract}
While assessing the effects of climate change at global or regional scales, local factors responsible for climate change are generalized, which results in the averaging of effects. However, climate change assessment is required at a micro-scale to determine the severity of climate change. To ascertain the impact of spatial scales on climate change assessments, trends and shifts in annual and seasonal (monsoon and non-monsoon), rainfall and temperature (minimum, average and maximum) were determined at three different spatial resolutions in India (Ajmer city, Ajmer District and Rajasthan State). The Mann-Kendall (MK), MK test with pre-whitening of series (MK-PW), and Modified Mann-Kendall (MMK) test, along with other statistical techniques were used for the trend analysis. The Pettitt-Mann-Whitney (PMW) test was applied to detect the temporal shift in climatic parameters. The Sen's slope and \% change in rainfall and temperature were also estimated over the study period (35 years). The annual and seasonal average temperature indicates significant warming trends, when assessed at a fine spatial resolution (Ajmer city) compared to a coarser spatial resolution (Ajmer District and Rajasthan State resolutions). Increasing trend was observed in minimum, mean and maximum temperature at all spatial scales; however, trends were more pronounced at a finer spatial resolution (Ajmer city). The PMW test indicates only the significant shift in non-monsoon season rainfall, which shows an increase in rainfall after 1995 in Ajmer city. The Kurtosis and coefficient of variation also revealed significant climate change, when assessed at a finer spatial resolution (Ajmer city) compared to a coarser resolution. This shows the contribution of land use/land cover change and several other local anthropogenic activities on climate change. The results of this study can be useful for the identification of optimum climate change adaptation and mitigation strategies based on the severity of climate change at different spatial scales.
\end{abstract}

Key words: climate change, India, Rajasthan State, scale effects, trend and shift analysis

\section{INTRODUCTION}

The issue of scale in hydrology is important for the linkages and integration of formulations at differ- ent spatial and temporal scales. However, this issue has not really been addressed adequately to date [BLÖSCHL, SIVAPALAN 1995; BORMANN et al. 1999; NALley et al. 2012; 2013; PINGAle et al. 2014; REN- 
SCHLER 2005]. The term scale refers to the characteristic length or time, which can be used either as a qualitative term or as a quantitative measure in space dimensions [BLÖSCHL 1999; RENSCHLER 2003]. The assessment of climate change involves two important issues: the spatial scale of analysis and the contribution of anthropogenic activity to climate change [SAADAT et al. 2011]. To explore the effect of climate change on water resources, it is necessary to understand the nonlinearity and complexity between the climate and land surface, and to consider the dependence of spatial scale [ADAMOWSKI et al. 2012a; CAMPISI et al. 2012; HAIDARY et al. 2013; JHA, PATRA 2009; TIWARI, ADAMOWSKI 2013].

Generally, the effect or problems of climate change in urban areas are more dominant than in rural areas [STATHOPOULOU, CARTALIS 2007]. The intensity of the urban heat island (UHI of the day time) is reflected by the temperature differences between urban and rural sites, which depend on the size, population and industrial development of a city, topography, physical layout, regional climate and meteorological conditions [ADAMOWSKI, PROKOPH 2013; OKE 1987]. Therefore, an understanding of climate change and its impact at different scales is very important for the prioritization of the most affected areas, and to avoid various problems, which include temperature increases, erratic precipitation patterns, flooding, water scarcity, loss of property, and various other environmental problems. An understanding of climate change and its impact at different scales will help in deciding on optimum adaptation strategies at local and regional levels [HALBE et al. 2013; KOLINJIVADI et al. 2014; 2015; STRAITH et al. 2014].

The IPCC has projected that global precipitation will increase; however, the trend at the regional scale is not clear. Further, climate change assessments need to be studied both quantitatively and qualitatively at the sub-national (i.e. state or province) and local scales for adequate adaptation and mitigation efforts [IPCC 2007]. In most previous studies, efforts have been made to address the problems of climate change at a single spatial scale, considering only a single aspect of assessment of climate change either at coarser spatial resolutions, i.e. country level (e.g. MATONDO, MSIBI [2001]; ARORA et al. [2005]; BASISTHA et al. [2007]; CARTWRIGHT, SimMONDS [2008]), district and State level (e.g. YOON, LEE [2003]), city or local level (e.g. DE, RAO [2004]; GOWDA et al. [2008]). However, a comparative study of climate change at different spatial scales has not been reported in the literature despite its importance due to the fact that climate change effects are more pronounced when assessed at finer spatial resolutions (local spatial scale) compared to coarser spatial resolutions (regional and global spatial scale).

Various trend analysis techniques have been used in the recent past to assess climate change in India (e.g. ARORA et al. [2005]; BASISTHA et al. [2007];
BASISTHA et al. [2009]; SAHOO, SMITH [2009]; PATRA et al. [2012]; JEGANATHAN, ANDIMUTHU [2013]), and other regions of the globe (e.g. EZBER et al. [2007]; MOTIEE, MCBEAN [2009]; ADAMOWSKI et al. [2009; 2010]; SABOOHI et al. [2012]; JiANG et al. [2013]; ARAGHI et al. [2015]). However, to date no studies have been reported in the literature that investigate the climate in terms of inter-seasonal and interannual variations and trends in temperature (minimum, average and maximum) and rainfall along with seasonal shifts at different spatial scales (city, district and state) including India. This type of study is necessary to understand the relationship between spatial scale severities of climate change.

The spatial resolutions of global climate models (GCMs) are normally quite coarse and this results in the loss of regional and local details of the climate, which are influenced by spatial heterogeneities due to anthropogenic factors [LIU et al. 2011; MCAVANEY et al. 2001; SCHUBERT 1998]. In the present study, an inverse approach has been proposed and evaluated using observed rainfall and temperature data at different scales. To understand the impact of spatial resolution on climate change, an attempt has been made in this study to assess climate change at different spatial scales (i.e. Ajmer city, Ajmer district and Rajasthan State). The paper first presents the study area and data that was used, as well as the methodology to assess climate change at different spatial scales. Subsequent to this, the findings of the study on scale implications for climate change assessment are presented using statistical trends and shift detection techniques such as the Mann-Kendall (MK) test, MK test with PreWhitening (MK-PW) of series, Modified MannKendall (MMK) test, and the Pettitt-Mann-Whitney (PMW) test. A comparative assessment of the different trend detection techniques for detecting trends and shifts in the annual and seasonal rainfall and temperature at different spatial scales is also presented.

\section{STUDY AREA AND DATA USED}

\section{STUDY AREA}

Ajmer city and district, along with Rajasthan State were chosen as the study areas for this study. Ajmer city is located between $26^{\circ} 20^{\prime}$ to $26^{\circ} 35^{\prime} \mathrm{N}$ latitude and $74^{\circ} 33^{\prime}$ to $74^{\circ} 45^{\prime} \mathrm{E}$ longitude, and it is the district headquarters of the Ajmer district (Fig. 1). Ajmer city is situated $132 \mathrm{~km}$ from Jaipur, the capital of Rajasthan, and spreads out over an area of approximately $85 \mathrm{~km}^{2}$. The Ajmer district extends from $25^{\circ} 38^{\prime}$ to $26^{\circ} 58^{\prime} \mathrm{N}$ latitude and $73^{\circ} 54^{\prime}$ to $75^{\circ} 22^{\prime} \mathrm{E}$ longitude (Fig. 1). It is situated almost in the heart of Rajasthan, which is bounded by the Nagaur district in the north, Jaipur and Tonk districts in the east, Bhilwara district in the south, and Pali district in the west. Ajmer district has an area of $8,481 \mathrm{~km}^{2}$ and population of 2,584,913, whereas Ajmer city has a population of 542,580 [Census... 2011]. 


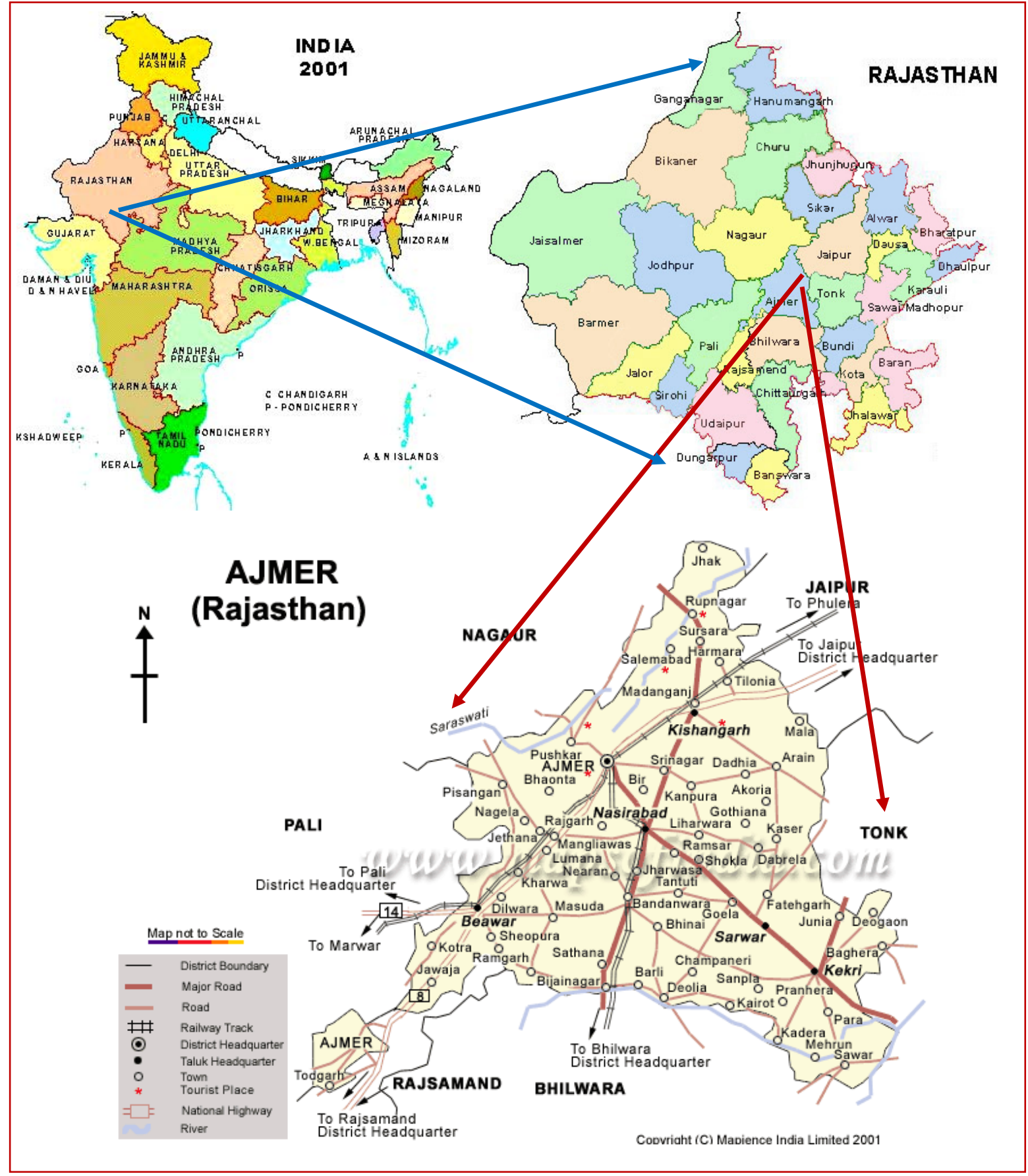

Fig. 1. Location of the study area

Rajasthan is the largest State of India, with an area of $342000 \mathrm{~km}^{2}$ and a population of 56.5 million, out of which $76.6 \%$ is rural. Geographically, Rajasthan State extends from $23^{\circ} 3.50^{\prime}$ to $30^{\circ} 14^{\prime} \mathrm{N}$ latitude and $69^{\circ} 27^{\prime}$ to $78^{\circ} 19^{\prime} \mathrm{E}$ longitude. The climate is characterized by low and erratic rainfall, extremes of diurnal and annual temperatures, low humidity, and high wind velocity. To the east of Aravali, the climate is semi-arid to sub-humid. The annual average rainfall is highly variable, and it is most erratic in the western region with frequent dry spells, punctuated occasionally by heavy downpours in some years that are associated with passing low pressure systems over the region. The Western and Southern districts of Rajasthan State frequently experience severe droughts. Coping with low rainfall, with a high coefficient of variation across time and space, is the major challenge [RATHOR 2005].

\section{DATA USED}

Gridded rainfall datasets have been used in many hydrological and climatological studies worldwide for hydro-climatic forecasting, climate attribution studies, and climate model performance assessments (e.g. TOZER et al. [2012]; DAS et al. [2013]; PINGALE et al. 
[2014]). Therefore, in the present study, gridded data sets of daily rainfall (i.e. $0.5^{\circ} \times 0.5^{\circ}$ ) and temperature (i.e. $1^{\circ} \times 1^{\circ}$ ) were used from the period 1971 to 2005 . These data sets were procured from the Indian Meteorological Department (IMD), Pune. These were developed at the Indian spatial scale by using the network of stations spread throughout India. Additional details of these data sets are given in PINGALE et al. [2014]. Daily rainfall and temperature (i.e. minimum, average and maximum) were extracted for Ajmer city, Ajmer district, and Rajasthan State spatial scales. The daily rainfall is available at $0.5^{\circ}$ and temperature is available at $1^{\circ}$ scales for the period of 1971-2005. The total number of grids of daily rainfall and temperature data were counted for Ajmer city, Ajmer district and Rajasthan State, respectively. These datasets were extracted for each grid. An average of annual and seasonal (monsoon and non-monsoon) rainfall

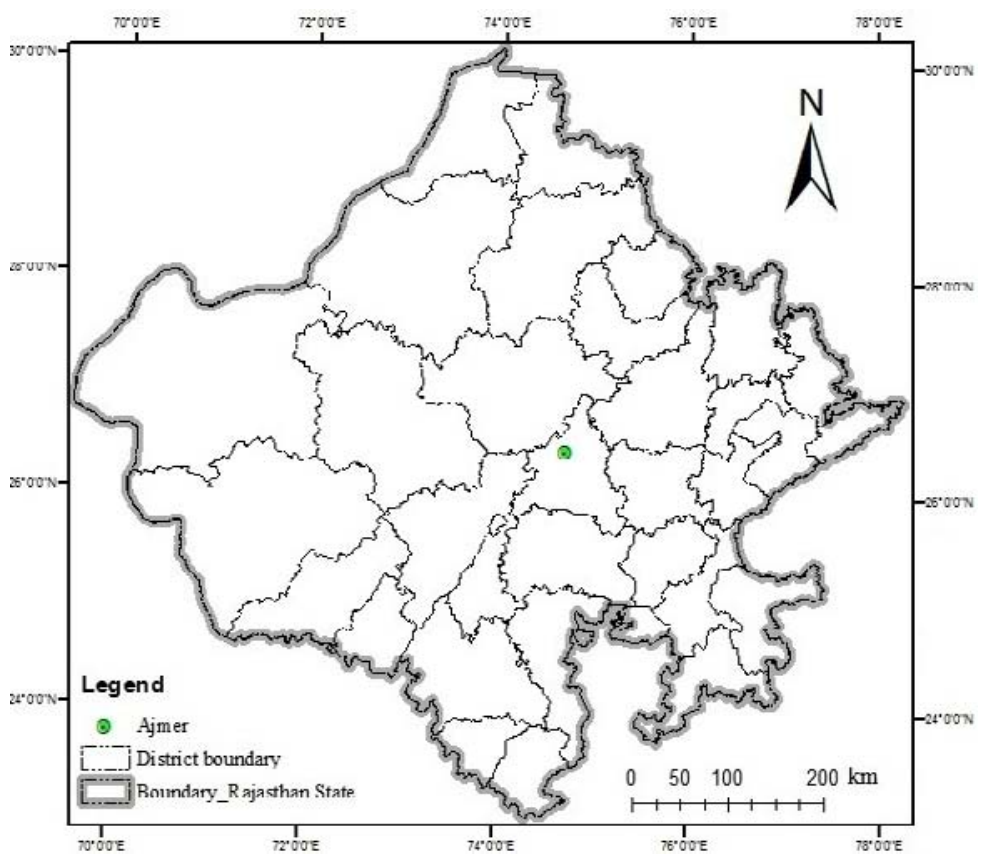

Fig. 2. The location of grid data extracted for the study area; source: own elaboration and temperature data were estimated for the grids covering the different spatial scales (Ajmer city, Ajmer district and Rajasthan State), respectively. These scales for the study area were selected taking into account the length and availability of records to assess trends and shifts in annual and seasonal (monsoon and non-monsoon) rainfall and temperature. A 35 year period was selected to maintain uniformity and consistency in the data, since data was not available over 35 years at these three scales. By using such short time period data, the errors associated with a given time period may carry over into future time periods. Therefore, it may have implications in the estimation of the autocorrelation function, which can lead to an error in the trend detection of climatic variables. However, despite this, this study is still important and different since it is important to understand the impact of spatial and temporal scale on climate change assessments for adaptation and planning measures in general. Here, the grids covering the city (Ajmer), district (Ajmer) and state (Rajasthan) levels were chosen to extract the daily rainfall and temperature data, and it was assumed that the grids covering the city, district and state represents the rainfall and temperature (1971-2005) (Fig. 2). These data were arranged according to monsoon season (June to September), non-monsoon season (January to May and October to December), and annual time scales for the years 1971-2005. The basic data quality checks were performed for gridded data sets and, also homogeneity, persistence and periodicity in the data were analyzed by autocorrelation analysis. Further, the gridded datasets for Ajmer city were validated using the observed rainfall in the preliminary data analysis, which were obtained from the Water Resources Department

of Rajasthan State. These data series have statistically similar statistical characteristics (i.e. mean and standard deviation).

\section{METHODOLOGY}

\section{TREND ANALYSIS}

Assessment of climate change at different spatial scales (i.e. local - Ajmer city, regional - Ajmer district and global - Rajasthan State) was carried out at seasonal and annual temporal scales in terms of detecting trends and shifts (i.e. MK, MK-PW, MMK and PMW test).

\section{Normalization and autocorrelation analysis of time series}

The outliers present in the time series were obtained using the normalized climatic time series. For more details about normalization and autocorrelation analysis of the time series refer PINGALE et al. [2014]. The autocorrelation test was performed to check the randomness and periodicity in the time series [MODARRES, SILVA 2007]. If lag $=1$ serial coefficients are not statistically significant, then the MK test can be applied to the original time series [KARPOUZOS et al. 2010; LUO et al. 2008]. The MMK test can be applied to statistically significant time series after removing the effect of serial correlation. For non-normal time series, the MK test is an appropriate choice for trend analysis [YUE, PILON 2004]. Therefore, the MK test was used wherever the autocorrelation was non-significant at $5 \%$ level of significance. 


\section{Mann-Kendall (MK) test}

The MK test is a non-parametric test for detecting trends in a time series [MANN 1945] where autocorrelation is non-significant. The non-linear trend as well as the turning point distribution is derived from Kendall test statistics [KENDALL 1975]. This method searches for a trend in a time series without specifying whether the trend is linear or nonlinear. It has been found to be a very useful tool for trend detection, and many researchers have used this test to assess the significance of trends in hydro-climatic time series such as water quality, stream flow, temperature and precipitation (e.g. LUDWIG et al. [2004]; ZHANG et al. [2004]; MCBEAN, MotiEe [2008]; RAI et al. [2010]; PATRA et al. [2012]). The details regarding MK test refer PINGALE et al. [2014].

\section{Mann-Kendall test with pre-whitening (MK-PW) of series}

The pre-whitening of time series involves the computation of serial correlation and removing correlation if the calculated serial correlation is significant at a significance level of 0.05 [BURN, ELNUR 2002]. The pre-whitening of a time series was accomplished as follows:

$$
X_{t}^{\prime}=\left(x_{k+1}-r \cdot x_{k}\right)
$$

where

$x_{k}=$ original time series with autocorrelation for time interval, $k$;

$X_{t}^{\prime}=$ pre-whitened time series;

$r_{\text {lag }}=1$ autocorrelation coefficient.

This pre-whitened time series was then subjected to the MK test for detecting the trend.

\section{Modified Mann-Kendall test (MMK)}

The MK test with pre-whitening of time series was used to detect a trend in a time series in the presence of autocorrelation [CUNDERLIK, BURN 2004]. However, pre-whitening reduces the detection rate of significant trends in the MK test [YUE, HASINO 2003]. Therefore, the MMK test was employed for trend detection of autocorrelated series [HAMED, RAO 1998; RAO et al. 2003]. A significant level of $10 \%$ was used for autocorrelation of the rank, which produced the best overall empirical significance level. The advantage of using corrected variance is that there is no need to either normalize data or their autocorrelation function and more details regarding MMK can be found in RAI et al. [2010].

\section{Sen's estimator of slope and percentage change over a period}

If a linear trend is present in a time series, then the true slope of a trend is estimated by using a simple non-parametric procedure [PINGALE 2014; SEN 1968; THEIL 1950]. The percentage change over a period of time was estimated using Theil and Sen's median slope and mean by assuming a linear trend [BASISTHA et al. 2009; YUE, HASHINO 2003] in a time series:

$$
\% \text { change }=\left(\frac{\text { median slope } \cdot \text { length of period }}{\text { mean }}\right)
$$

\section{Pettitt-Mann-Whitney (PMW) test}

The PMW test was used for the determination of shift in the climatological time series. This test was performed using the evaluation version of Xlstat 2011 software. This test can be briefly described using PMW statistics which can be found in KIELY et al. [1998] and BASISTHA et al. [2009]. A series consisting of probabilities of change point at each year were obtained for shift detection in the time series of annual and seasonal (monsoon and non-monsoon) rainfall and temperature at different spatial scales.

\section{RESULTS AND DISCUSSION}

\section{TREND ANALYSIS AT DIFFERENT SPATIAL SCALES}

\section{Autocorrelation and normalisation analysis}

Before applying the statistical trend detection methods, autocorrelation analysis were performed to identify the suitable trend analysis method, and the performance of original and normalized series of rainfall and temperature. Generally, Box and Jenkins suggest $K \cong N / 4$ (where, $N=$ number of years and $K=$ number of lags). Therefore, autocorrelation analysis up to the $9^{\text {th }}$ lag was carried out for annual and seasonal (monsoon and non-monsoon) rainfall and temperature (minimum, average and maximum) at three spatial scales (Ajmer city, Ajmer district and Rajasthan State). The sample plot of autocorrelation at different lags (correlogram) for Ajmer city is presented in Fig. 3. The upper and lower bound were decided by the $95 \%$ confidence interval to test the limits of the autocorrelation coefficient. The autocorrelation at lag $=1$ were observed for seasonal and annual rainfall and temperature at the 0.05 significance level. The autocorrelation was considered as significant if it is greater than 0.19 . The MK test was applied for nonsignificant, and the MMK test for significant, rainfall and temperature series at auto-correlated series of $\operatorname{lag}=1$. The autocorrelation coefficient at lag $=1$ is important because the dependence of physical systems on past values is likely to be strongest for the most recent past [WAGESHO et al. 2013].

The summary of autocorrelation analysis at lag $=1$ of the rainfall and temperature is given in Table 1 for different spatial scales. The results suggest that the MK test can be applied for the monsoon season rainfall and temperature for Ajmer city, Ajmer district (except rainfall) and Rajasthan State. The 
a)
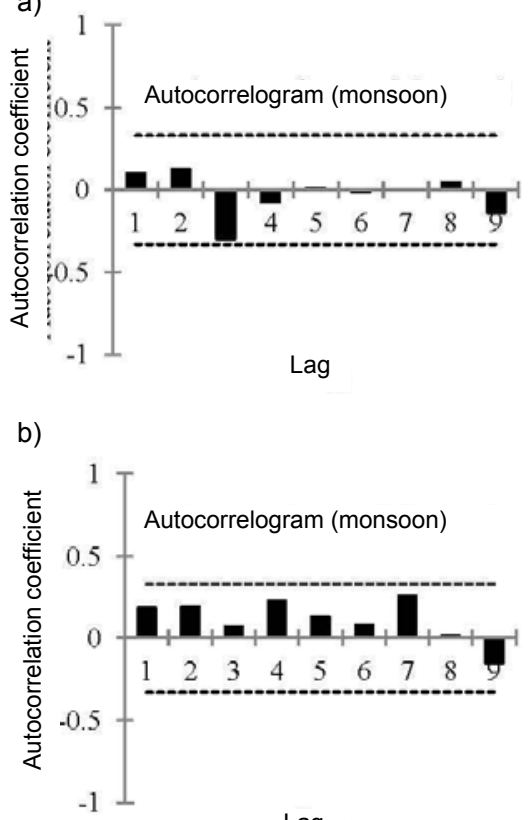

Lag

c)

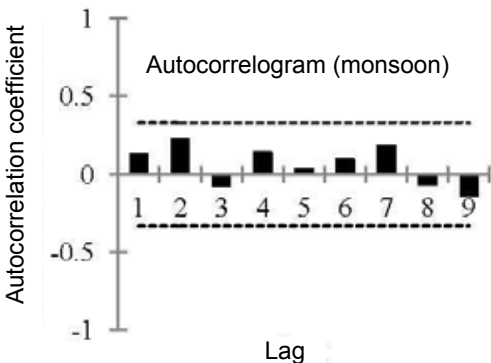

d)

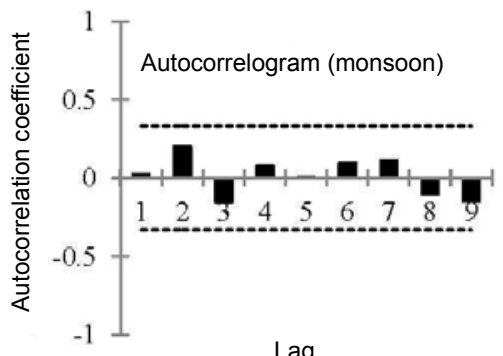

Lag
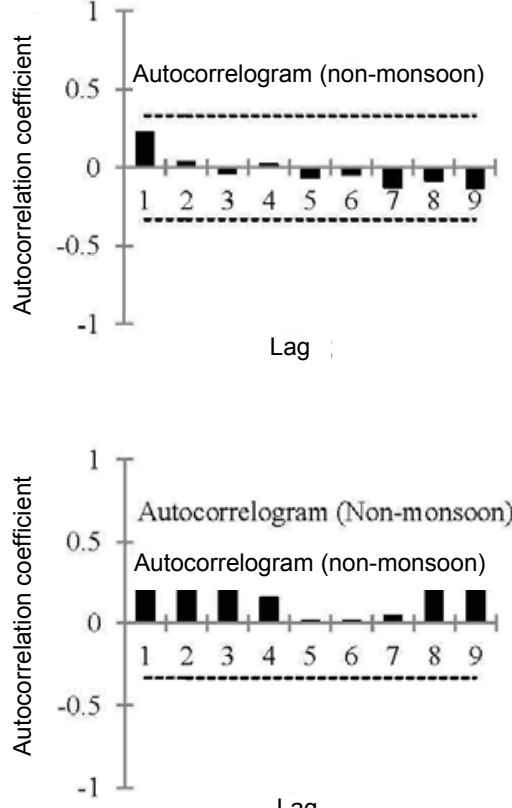

Lag

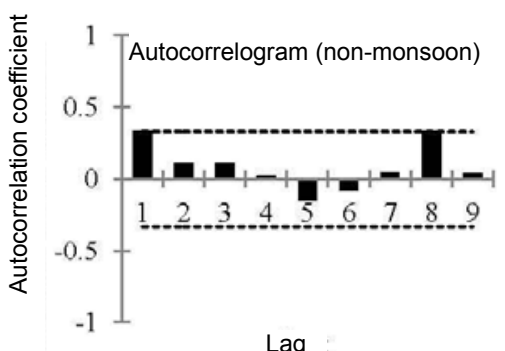

Lag

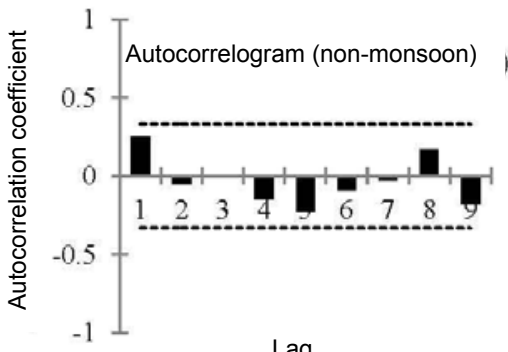

Lag

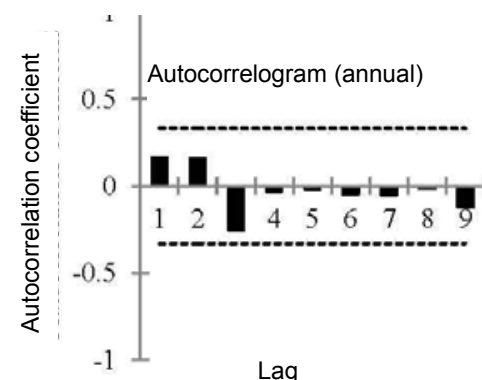

Lag

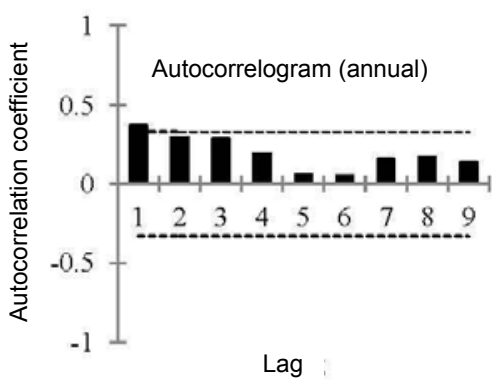

Lag
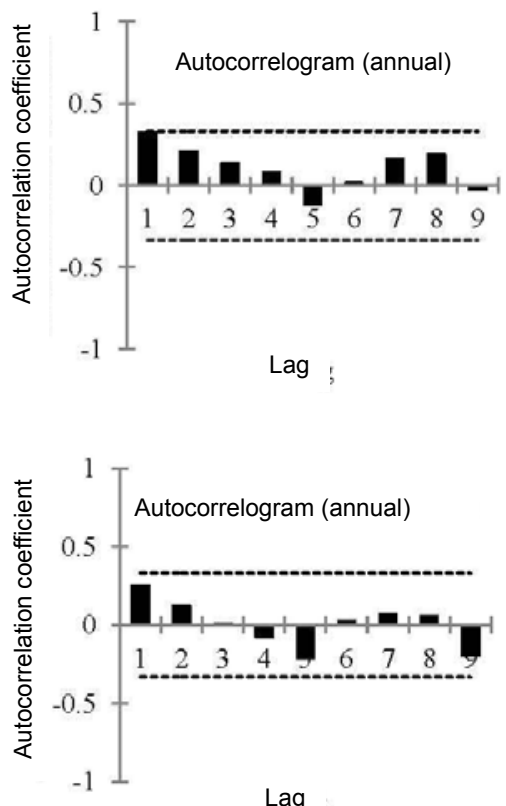

Lag

Fig. 3. Autocorrelation analysis of seasonal and annual rainfall and temperature in Ajmer city; a) rainfall, b) minimum temperature, c) average temperature, d) maximum temperature; source: own study

MMK test can be applied for trend detection in monsoon season rainfall for Ajmer district since autocorrelation was found to be significant. It was observed from autocorrelation analysis that the MMK test can be applied for non-monsoon season rainfall and temperature at all three spatial scales, except non-monsoon season rainfall for Rajasthan State (Tab. 1). However, autocorrelation analysis on the annual series suggests that the MMK test can be applied for Ajmer district rainfall and temperature, except Ajmer city and Rajasthan State, where the MK test can be applied for annual rainfall (Tab. 1).

\section{Trend analysis}

After autocorrelation analysis, trend analysis was carried out separately at a $10 \%$ level of significance using the MK, MK-PW, and MMK test for annual and seasonal average rainfall and temperature at the three spatial scales. The results were compared with each other to estimate the trends in average rainfall and temperature using the different trend methods. The detail trend analysis results are presented at spatial scales (Ajmer city, Ajmer district and Rajasthan State) (Tab. 2). These results indicate that there is no 
Table 1. Summary of autocorrelation analysis at lag $=1$ for climatic variables

\begin{tabular}{|c|c|c|c|c|c|c|c|c|c|}
\hline \multirow{2}{*}{ Parameters } & \multicolumn{3}{|c|}{ Monsoon season } & \multicolumn{3}{|c|}{ Non-monsoon season } & \multicolumn{3}{|c|}{ Annual } \\
\hline & $\mathrm{AJC}$ & AJD & $\mathrm{RJ}$ & AJC & AJD & RJ & AJC & AJD & $\mathrm{RJ}$ \\
\hline Rainfall & 0.101 & 0.225 & 0.094 & 0.223 & 0.214 & 0.098 & 0.162 & 0.276 & 0.089 \\
\hline Minimum temperature & 0.179 & 0.125 & -0.010 & 0.420 & 0.393 & 0.447 & 0.371 & 0.337 & 0.295 \\
\hline Average temperature & 0.127 & 0.112 & 0.037 & 0.330 & 0.306 & 0.257 & 0.324 & 0.296 & 0.272 \\
\hline Maximum temperature & 0.024 & 0.034 & -0.006 & 0.248 & 0.227 & 0.230 & 0.254 & 0.235 & 0.218 \\
\hline
\end{tabular}

Explanations: AJC, AJD and RJ represent Ajmer city, Ajmer district and Rajasthan State, respectively. Highlighted bold values indicates significant autocorrelation coefficient at 0.05 level of significance.

Source: own study.

Table 2. Trend analysis of climatic variables at different spatial scales

\begin{tabular}{|c|c|c|c|c|c|c|c|c|c|c|c|c|c|c|c|c|c|c|}
\hline \multirow{4}{*}{ Season } & \multicolumn{18}{|c|}{ Test/scale/variable } \\
\hline & \multicolumn{6}{|c|}{ MK test } & \multicolumn{6}{|c|}{ MK-PW test } & \multicolumn{6}{|c|}{ MMK test } \\
\hline & \multicolumn{2}{|c|}{ AJC } & \multicolumn{2}{|c|}{ AJD } & \multicolumn{2}{|c|}{ RJ } & \multicolumn{2}{|c|}{$\mathrm{AJC}$} & \multicolumn{2}{|c|}{ AJD } & \multicolumn{2}{|c|}{ RJ } & \multicolumn{2}{|c|}{ AJC } & \multicolumn{2}{|c|}{ AJD } & \multicolumn{2}{|c|}{ RJ } \\
\hline & $S$ & $Z_{m k}$ & $S$ & $Z_{m k}$ & $S$ & $Z_{m k}$ & $S$ & $Z_{m k}$ & $S$ & $Z_{m k}$ & $S$ & $Z_{m k}$ & $S$ & $Z_{m k}$ & $S$ & $Z_{m k}$ & $S$ & $Z_{m k}$ \\
\hline \multicolumn{19}{|c|}{ Rainfall } \\
\hline Annual & 9 & 0.11 & -11 & -0.14 & -63 & -0.88 & 9 & 0.11 & -11 & -0.14 & -62 & -0.87 & 9 & 0.11 & -11 & -0.14 & -63 & -0.88 \\
\hline Monsoon season & -21 & -0.28 & -5 & -0.06 & \begin{tabular}{|l|}
-69 \\
\end{tabular} & -0.97 & -19 & -0.26 & -6 & -0.07 & -68 & -0.95 & -21 & -0.28 & -5 & -0.76 & -69 & -1.03 \\
\hline $\begin{array}{l}\text { Non-monsoon } \\
\text { season }\end{array}$ & 85 & 1.19 & 19 & 0.26 & 69 & 0.97 & 75 & 1.05 & 19 & 0.26 & 71 & 0.99 & 85 & 1.19 & 19 & 0.22 & 69 & 0.97 \\
\hline \multicolumn{19}{|c|}{ Minimum temperature } \\
\hline Annual & 272 & 3.85 & 239 & 3.38 & 229 & 3.24 & 273 & 3.86 & 307 & 4.35 & 228 & 3.22 & 272 & 3.12 & 239 & 3.38 & 229 & 3.24 \\
\hline Monsoon season & 264 & 3.74 & 156 & 2.20 & 191 & 2.70 & 165 & 2.33 & 297 & 4.21 & 193 & 2.73 & 165 & 2.33 & 156 & 2.20 & 191 & 2.01 \\
\hline $\begin{array}{l}\text { Non-monsoon } \\
\text { season }\end{array}$ & 165 & 2.33 & 237 & 3.35 & 205 & 2.90 & 263 & 3.72 & 240 & 3.40 & 205 & 2.90 & 264 & 3.73 & 237 & 3.35 & 205 & 2.90 \\
\hline \multicolumn{19}{|c|}{ Average temperature } \\
\hline Annual & 239 & 3.38 & 230 & 3.25 & 214 & 3.03 & 237 & 3.35 & 295 & 4.18 & 215 & 3.04 & 239 & 3.38 & 230 & 3.67 & 214 & 3.78 \\
\hline Monsoon season & 144 & 2.03 & 130 & 1.83 & 142 & 2.00 & 144 & 2.03 & 280 & 3.96 & 142 & 2.00 & 144 & 2.03 & 130 & 1.83 & 142 & 2.00 \\
\hline $\begin{array}{l}\text { Non-monsoon } \\
\text { season }\end{array}$ & 225 & 3.18 & 203 & 2.87 & 174 & 2.46 & 225 & 3.18 & 230 & 3.25 & 173 & 2.44 & 225 & 5.29 & 203 & 2.87 & 174 & 3.14 \\
\hline \multicolumn{19}{|c|}{ Maximum temperature } \\
\hline Annual & 146 & 2.06 & 137 & 1.93 & 158 & 2.23 & 147 & 2.07 & 165 & 2.33 & 155 & 2.19 & 146 & 2.06 & 137 & 1.93 & 158 & 3.55 \\
\hline Monsoon season & 88 & 1.24 & 104 & 1.46 & 100 & 1.41 & 87 & 1.22 & 107 & 1.51 & 101 & 1.42 & 88 & 0.95 & 104 & 1.46 & 100 & 1.41 \\
\hline $\begin{array}{l}\text { Non-monsoon } \\
\text { season }\end{array}$ & 99 & 1.39 & 93 & 1.31 & 104 & 1.46 & 99 & 1.39 & 105 & 1.48 & 105 & 1.48 & 99 & 1.39 & 93 & 1.31 & 104 & 1.76 \\
\hline
\end{tabular}

Explanations: AJC, AJD and RJ represent Ajmer city, Ajmer district and Rajasthan State, respectively; $S$ and $Z_{m k}$ are defined in the text. Trends are highlighted in bold at $10 \%$ level of significance.

Source: own study.

significant difference in trend detection using these tests at the three spatial scales. This may be due to the difference in probability related to the degree of normality of the distribution [HUTH, POKORNA 2004].

No trend was detected in annual and seasonal (monsoon and non-monsoon) average rainfall at 10\% level of significance by the three trend tests at the three spatial scales. The null hypothesis of no trend indicates that the evidence for trend in rainfall is not sufficient at the $10 \%$ significance level at these scales. Similarly, some studies also observed no trend in rainfall at the national (India) scale [ARORA et al. 2005; DASH et al. 2007; HINGANE 1995; KUMAR et al. 2010; PANT, Kumar 1997]. Kumar et al. [2010] found small changes in annual rainfall in north-west India. However, significant increasing and decreasing trends in rainfall were also found in other regions of India (e.g. BASISTHA et al. [2007]; RAI et al. [2008]). Significant increasing trends were observed in minimum and average temperature in the monsoon and nonmonsoon season, and annual time series. Positive trends in seasonal and annual minimum temperature have also observed by other researchers in India (e.g. JAIN et al. [2013]). The monsoon and non-monsoon season average maximum temperature did not show significant trends. However, a significant increasing trend was observed in average annual maximum temperature at all three spatial scales.

After the MK test, Sen's estimator of slope was applied to determine the change per unit time in annual and seasonal rainfall and temperature for Ajmer city, Ajmer district, and Rajasthan State (Tab. 3). The negative sign of Sen's slope indicates a downward slope and a positive sign indicates an upward slope in trend. The Sen's slope and percentage change in average rainfall and temperature were compared for annual and seasonal time scales at the three spatial scales. The statistically significant upward slopes were observed in monsoon season, non-monsoon season, and annual average and minimum temperature at all three spatial scales (Figs. 4 to 6). It was observed that annual average minimum temperature increased at a rate of $0.037^{\circ} \mathrm{C}, 0.032^{\circ} \mathrm{C}$ and $0.028^{\circ} \mathrm{C}$ at Ajmer city, Ajmer district, and Rajasthan State, respectively, 
Table 3. Sen's slope and percentage change of climatic variables at different spatial scales

\begin{tabular}{|c|c|c|c|c|c|c|}
\hline \multirow{2}{*}{ Season } & \multicolumn{2}{|c|}{ Ajmer city } & \multicolumn{2}{|c|}{ Ajmer district } & \multicolumn{2}{|c|}{ Rajasthan State } \\
\hline & Sen's slope & $\%$ change & Sen's slope & $\%$ change & Sen's slope & $\%$ change \\
\hline \multicolumn{7}{|c|}{ Rainfall } \\
\hline Annual & 0.171 & 1.245 & -0.435 & -0.032 & -2.194 & -17.445 \\
\hline Monsoon season & -0.344 & -2.710 & -0.603 & -0.049 & -2.323 & -20.885 \\
\hline Non-monsoon season & 0.468 & 45.410 & 0.067 & 0.053 & 0.374 & 26.568 \\
\hline \multicolumn{7}{|c|}{ Minimum temperature } \\
\hline Annual & 0.037 & 6.992 & 0.032 & 0.061 & 0.028 & 5.398 \\
\hline Monsoon season & 0.026 & 3.635 & 0.021 & 0.029 & 0.023 & 3.183 \\
\hline Non-monsoon season & 0.043 & 9.857 & 0.038 & 0.089 & 0.031 & 7.317 \\
\hline \multicolumn{7}{|c|}{ Average temperature } \\
\hline Annual & 0.030 & 4.097 & 0.028 & 0.037 & 0.021 & 2.947 \\
\hline Monsoon season & 0.023 & 2.703 & 0.219 & 0.251 & 0.022 & 2.552 \\
\hline Non-monsoon season & 0.030 & 4.499 & 0.029 & 0.044 & 0.021 & 3.184 \\
\hline \multicolumn{7}{|c|}{ Maximum temperature } \\
\hline Annual & 0.022 & 2.348 & 0.021 & 0.022 & 0.020 & 2.147 \\
\hline Monsoon season & 0.017 & 1.703 & 0.022 & 0.021 & 0.023 & 2.247 \\
\hline Non-monsoon season & 0.019 & 2.105 & 0.019 & 0.021 & 0.015 & 1.704 \\
\hline
\end{tabular}

Explanations: bold shows statistically significant Sen's slope at $10 \%$ level of significance.

Source: own study.
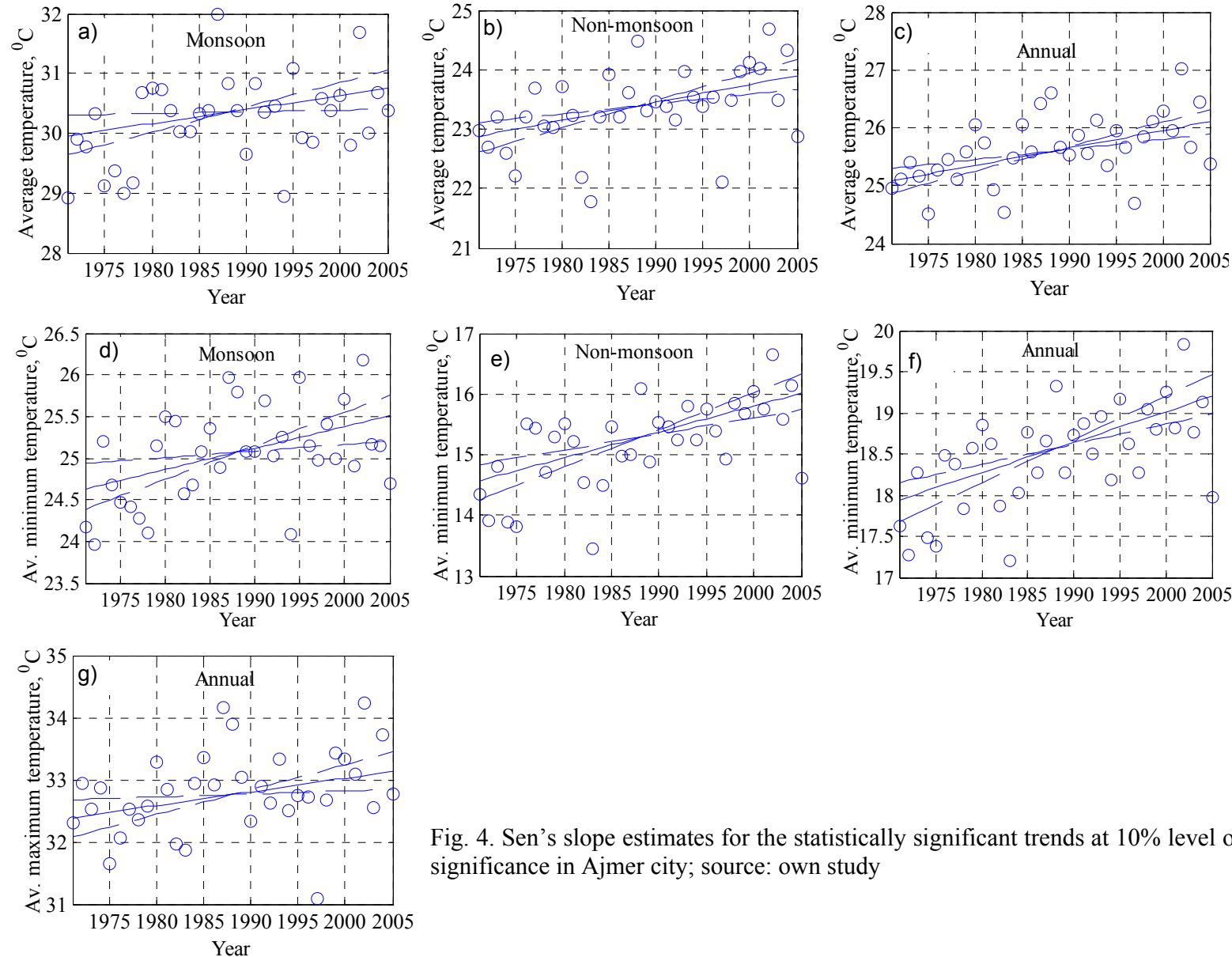

Fig. 4. Sen's slope estimates for the statistically significant trends at $10 \%$ level of significance in Ajmer city; source: own study

whereas it increased at a rate of $0.026^{\circ} \mathrm{C}, 0.021^{\circ} \mathrm{C}$ and $0.023^{\circ} \mathrm{C}$ in the monsoon season, and $0.043^{\circ} \mathrm{C}$, $0.038^{\circ} \mathrm{C}$ and $0.031^{\circ} \mathrm{C}$ in the non-monsoon season, respectively. Similarly, average temperature increased at a rate of $0.030^{\circ} \mathrm{C}, 0.028^{\circ} \mathrm{C}$ and $0.021^{\circ} \mathrm{C}, 0.023^{\circ} \mathrm{C}$ $0.219^{\circ} \mathrm{C}$ and $0.022^{\circ} \mathrm{C}$, and $0.30^{\circ} \mathrm{C}, 0.029^{\circ} \mathrm{C}$ and
$0.021{ }^{\circ} \mathrm{C}$ during the annual, monsoon and non-monsoon season, respectively. However, annual average maximum temperature had an increasing trend at a rate of $0.022^{\circ} \mathrm{C}, 0.021^{\circ} \mathrm{C}$ and $0.020^{\circ} \mathrm{C}$ per year at these spatial scales (Tab. 3). This is in agreement with the observations (i.e. increase in temperature) made 


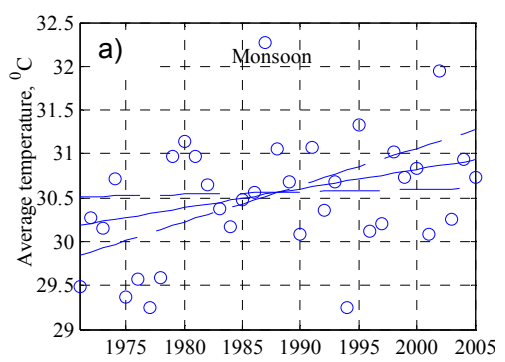

Year
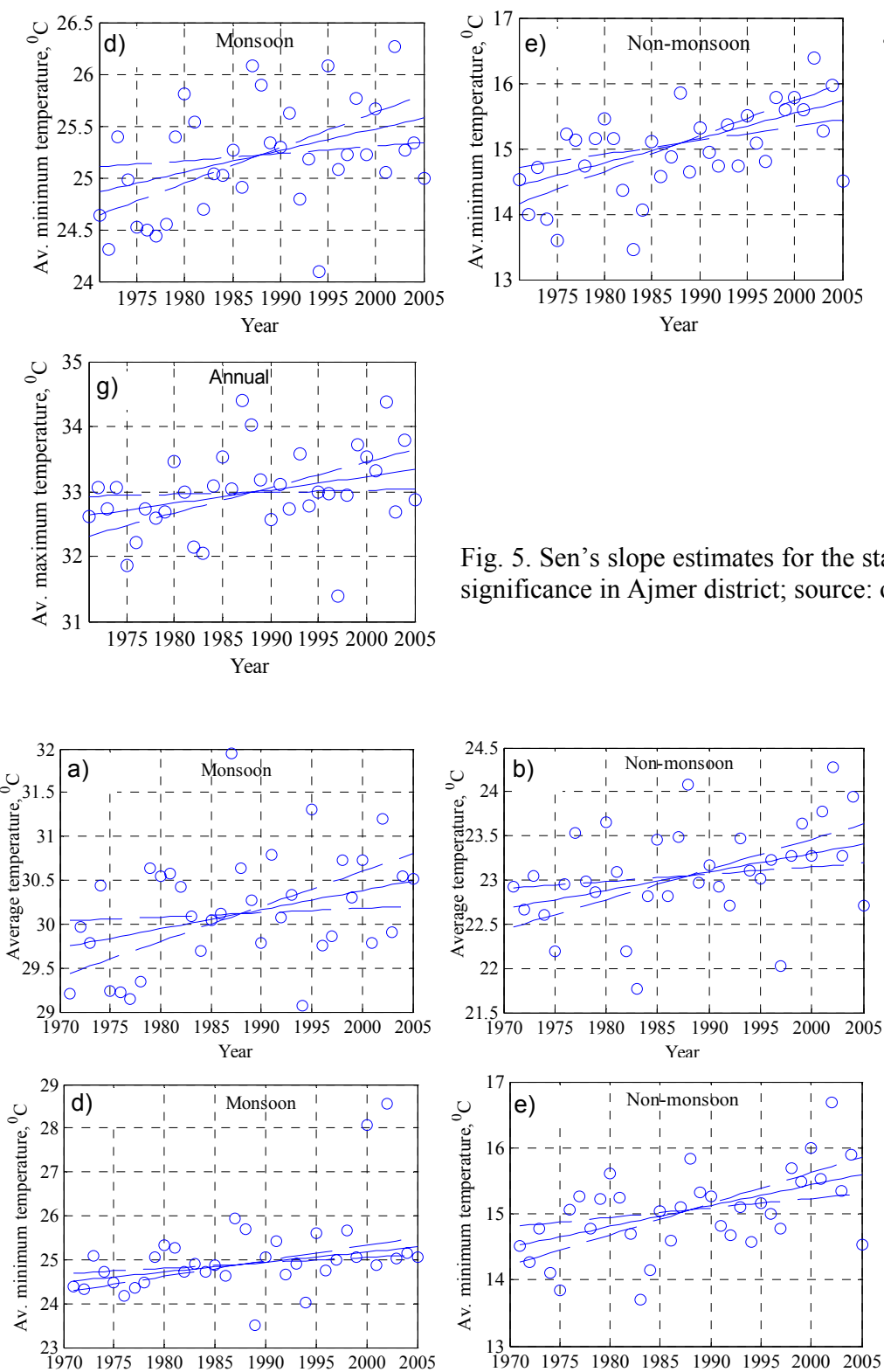

Year

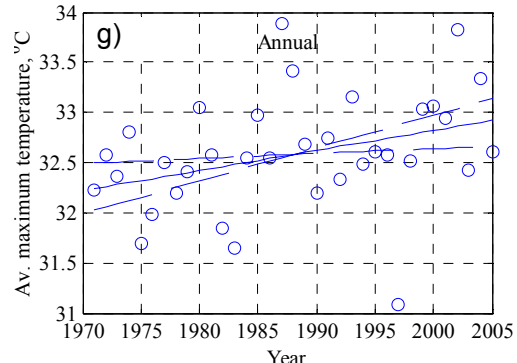

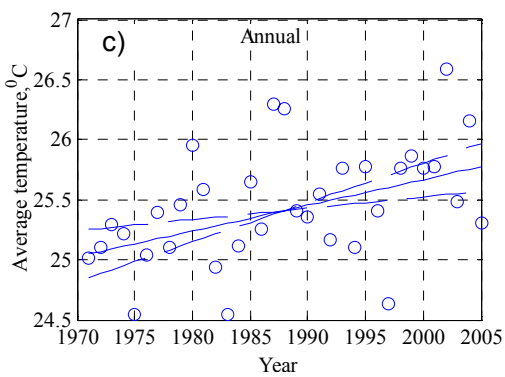

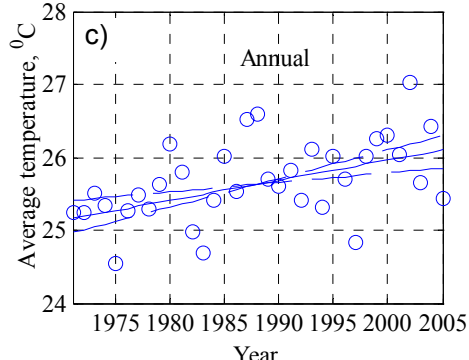

Year

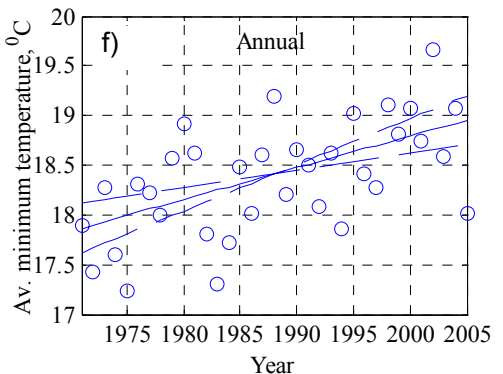

Fig. 5. Sen's slope estimates for the statistically significant trends at $10 \%$ level of significance in Ajmer district; source: own study
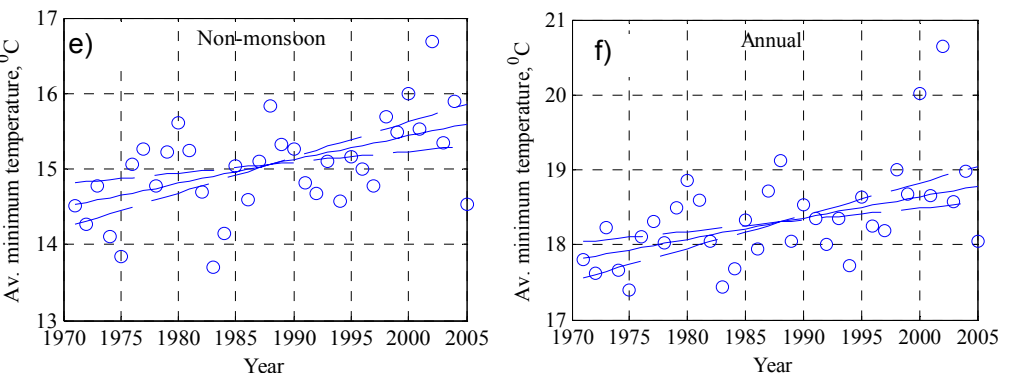

Fig. 6. Sen's slope estimates for the statistically significant trends at $10 \%$ level of significance in Rajasthan State; source: own study 
by several researchers in India (e.g. KOTHYARI, SINGH [1996]; Kothawale, Kumar [2005]; JaIn et al. [2013]). JAIN et al. [2013] found a rising trend in temperature (minimum, maximum, average and temperature range) in the northeast region of India.

The results of annual and seasonal average temperature (annual: $0.037^{\circ} \mathrm{C}>0.032^{\circ} \mathrm{C}>0.028^{\circ} \mathrm{C}$; non-monsoon season: $0.043^{\circ} \mathrm{C}>0.038^{\circ} \mathrm{C}>0.031^{\circ} \mathrm{C}$ ) shows significant changes, when assessed at a finer spatial resolution (i.e. Ajmer city compared to the coarser resolutions of Ajmer district and Rajasthan State). This indicates that climate change effects are more pronounced at a local scale (urban) compared to regional and global scales. This difference in climate change in urban areas is mainly due to local anthropogenic activities such as land use change, urbanization and industrialization [FUJIBE 1995; GADGIL, DHORDE 2005]. The significant changes of climate, and especially temperature, in rural and urban areas has also been reported by other researchers (e.g. ChUNG et al. [2004]; CUI, SHI [2012]; ADAMOWSKI, PROKOPH [2013]). ADAMOWSKI and PROKOPH [2013], and CHUNG et al. [2004] reported that annual temperature increase is higher in urban areas than the rural areas. The results indicate that the level of uncertainty in climate prediction may be higher if assessed at coarser spatial resolutions compared to finer resolutions. In this study, average temperature increased at different spatial scales (Ajmer city, Ajmer district and Rajasthan State); however, in contrast the IPCC observed both an average increase and decrease in temperature at the global level [IPCC 2007].

\section{CHANGE POINT YEARS AT DIFFERENT SPATIAL SCALES USING THE SHIFT DETECTION TEST}

The identification of the change point year is necessary for planning adaptation measures, which can provide valuable information [FISCHER et al. 2012]. Abrupt shifts also provide evidence of climate change in a region. Therefore, temporal shift detection in seasonal and annual average rainfall and temperature was carried out using the PMW test at three different spatial scales. In Ajmer city, the PMW test revealed that significant shifts were observed only in non-monsoon season rainfall and which shows an increasing trend (Fig. 7a). Also, trend analysis results show an increasing trend in non-monsoon season rainfall at 10\% level of significance (Tab. 2). The 1995 was observed to be the most probable change point in non-monsoon season average rainfall in Ajmer city. The test results suggest that significant shifts in rainfall were not observed in Ajmer district and Rajasthan State (Tab. 4). BASISTHA et al. [2009] determined the most probable change point year (i.e. 1964) in annual and monsoon rainfall in the Himalayan region of India. They found an increasing trend up to 1964 and a decreasing trend after (1965-1980). The very different change point years at the India level (1932) and north-west India (1941) level were also determined for the period 1902-1980.
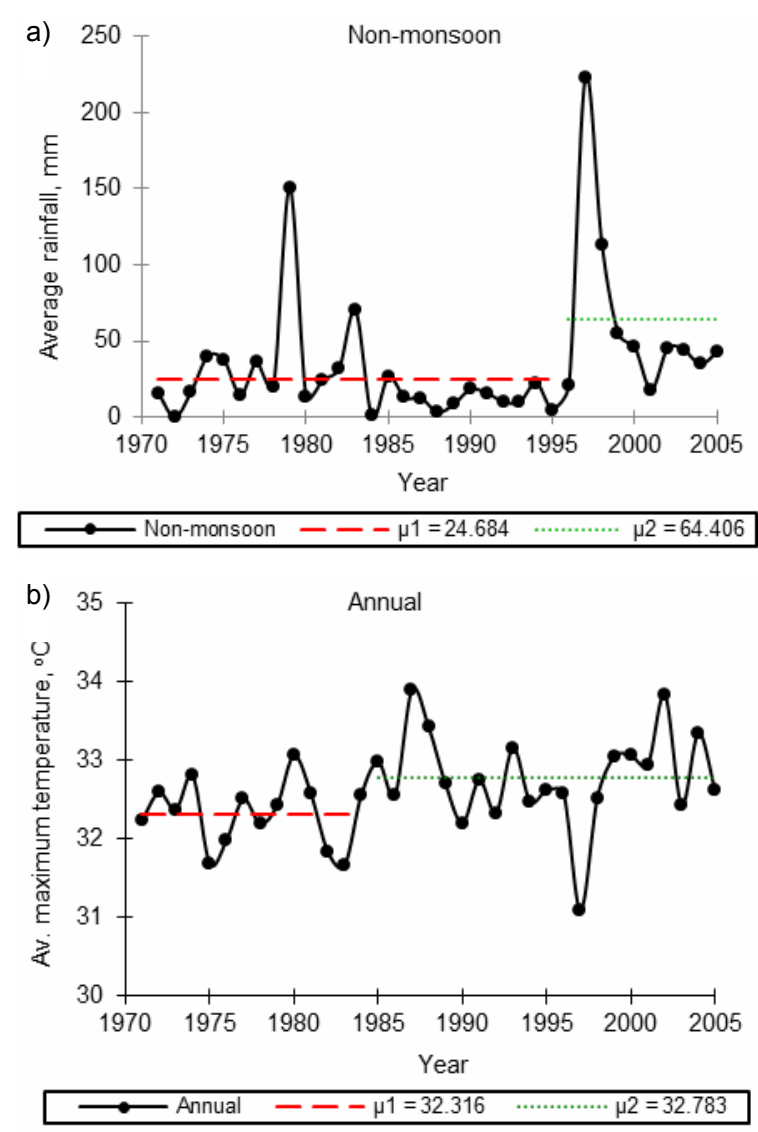

Fig. 7. Shift detection in non-monsoon season (a) average rainfall (in Ajmer city) and annual (b) average maximum temperature in Rajasthan State; source: own study

Table 4. Shifts in rainfall and temperature for different spatial scales

\begin{tabular}{|l|c|c|c|}
\hline \multirow{4}{*}{ Season } & \multicolumn{3}{c|}{ Change years } \\
\cline { 2 - 4 } & Ajmer city & $\begin{array}{c}\text { Ajmer } \\
\text { district }\end{array}$ & $\begin{array}{c}\text { Rajasthan } \\
\text { State }\end{array}$ \\
\hline Rainfall \\
\hline Mnnual & $*$ & $*$ & $*$ \\
\hline Nonsoon season & $*$ & $*$ & $*$ \\
\hline \multicolumn{4}{|c|}{ Minimum temperature } \\
\hline Annual & $1986-1987$ & $1986-1987$ & $1986-1987$ \\
\hline Monsoon season & $1978-1979$ & $1978-1979$ & $*$ \\
\hline Non-monsoon season & $1987-1988$ & $1987-1988$ & $1986-1987$ \\
\hline \multicolumn{4}{|c|}{ Average temperature } \\
\hline Annual & $1984-1985$ & $1984-1985$ & $1984-1985$ \\
\hline Monsoon season & $1978-1979$ & $1978-1979$ & $1978-1979$ \\
\hline Non-monsoon season & $1984-1985$ & $1984-1985$ & $*$ \\
\hline \multicolumn{4}{|c|}{ Maximum temperature } \\
\hline Annual & $1983-1984$ & $1983-1984$ & $*$ \\
\hline Monsoon season & $*$ & $*$ & $*$ \\
\hline Non-monsoon season & $*$ & $*$ & $*$ \\
\hline
\end{tabular}

Explanations: * denote shift have not observed in rainfall and temperature during 1971-2005.

Source: own study.

In the case of minimum, average, and maximum temperature, there is a positive (increase) significant shift observed at seasonal and annual temporal scales (except, annual maximum temperature, monsoon sea- 
son minimum and non-monsoon season average temperature at Rajasthan State and, seasonal (i.e. monsoon and non-monsoon) maximum temperature at three spatial scales) (Figs. $7 b$ to 13 and Table 4). The average minimum temperature showed significant shifts during 1986-1987 (monsoon), 1978-1979 (nonmonsoon) and 1987-1988 (annual) at all three spatial scales, except monsoon season average minimum temperature in Rajasthan State. Similarly, average temperature showed significant shifts during 19841985 (monsoon), 1978-1979 (non-monsoon) and 1984-1985 (annual) at all three spatial scales, except non-monsoon season average temperature in Rajasthan State. However, only the significant shift in
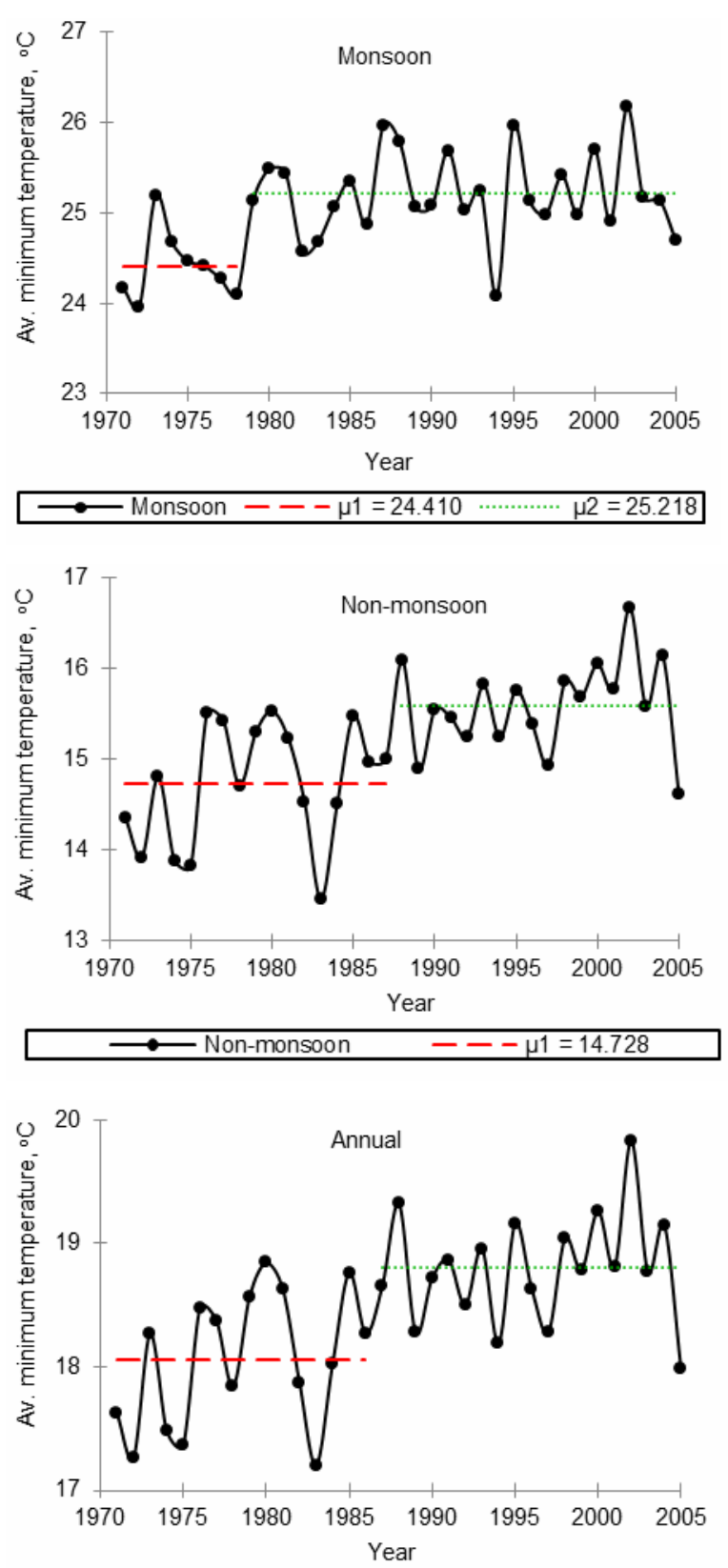

$\longrightarrow$ Annual $\quad---\mu 1=18.055 \quad \cdots \cdots \cdots \cdots \cdots \cdots, \mu 2=18.799$

Fig. 8. Shift detection of average minimum temperature in Ajmer city; source: own study

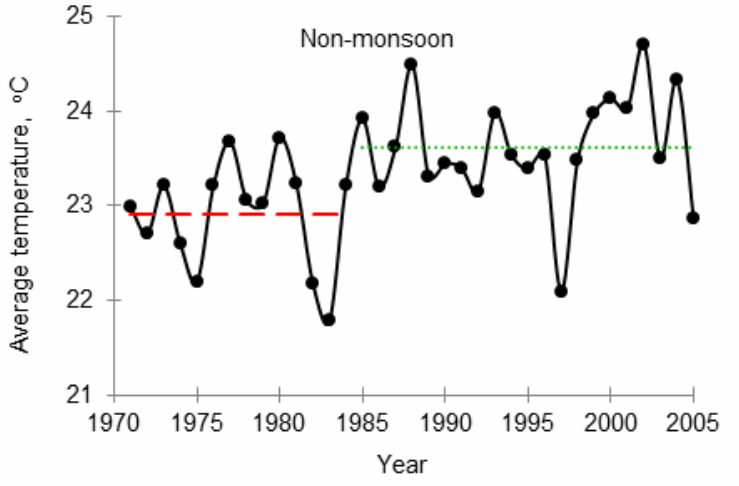

$\longrightarrow$ C Non-monsoon $---\mu 1=22.914 \cdots \cdots \cdots \cdots \cdots \cdots, \mu 2=23.622$
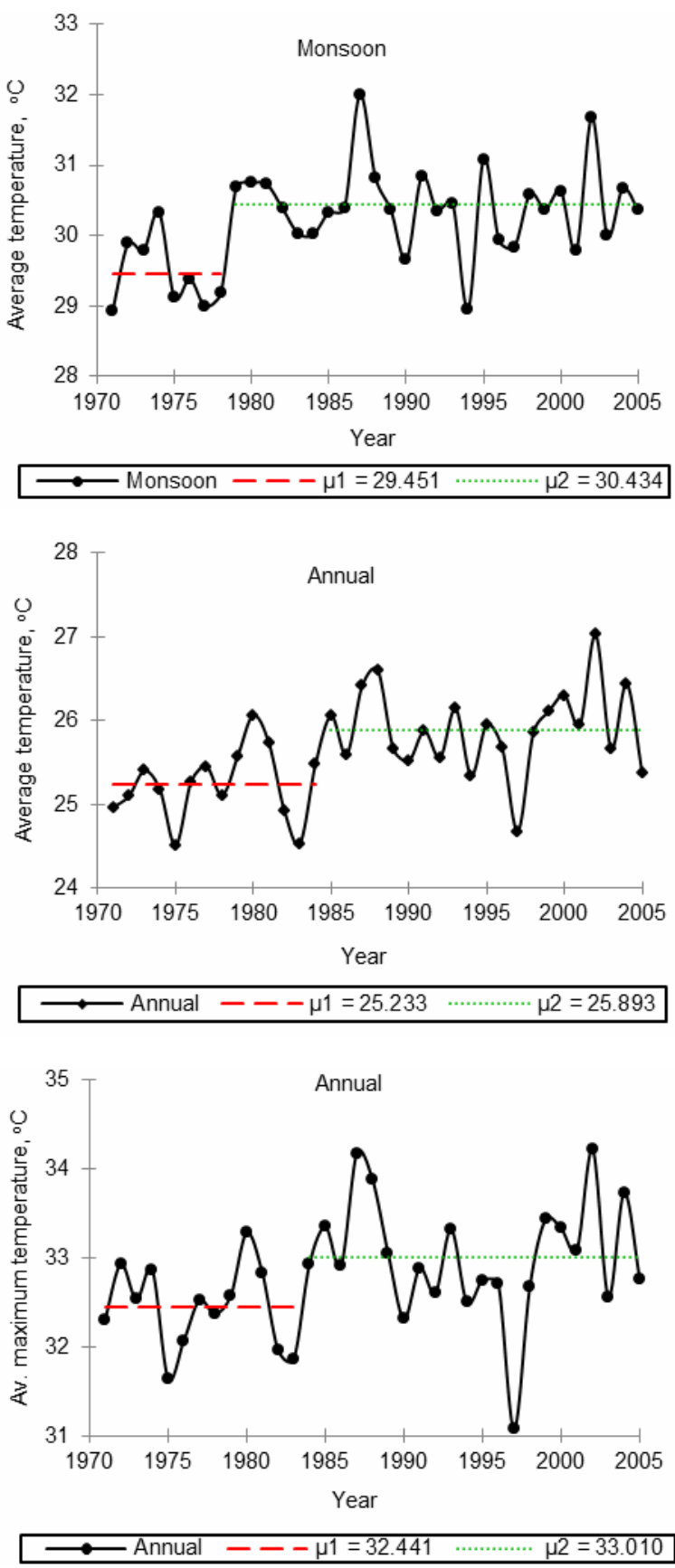

Fig. 9. Shift detection of average and average maximum temperature in Ajmer city; source: own study 

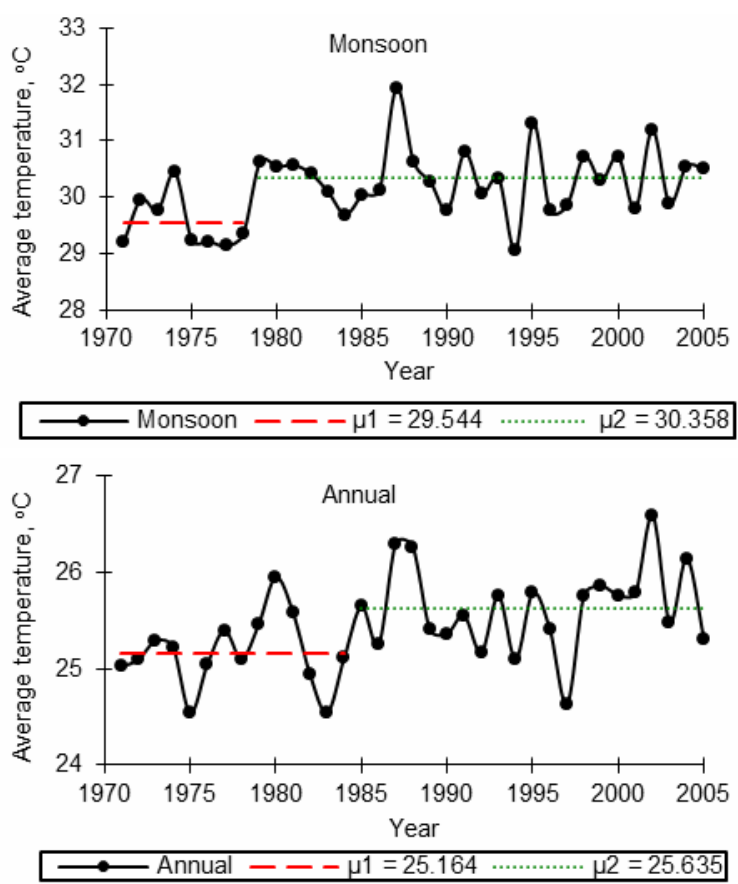

Fig. 10. Shift detection of average temperature in Rajasthan State; source: own study
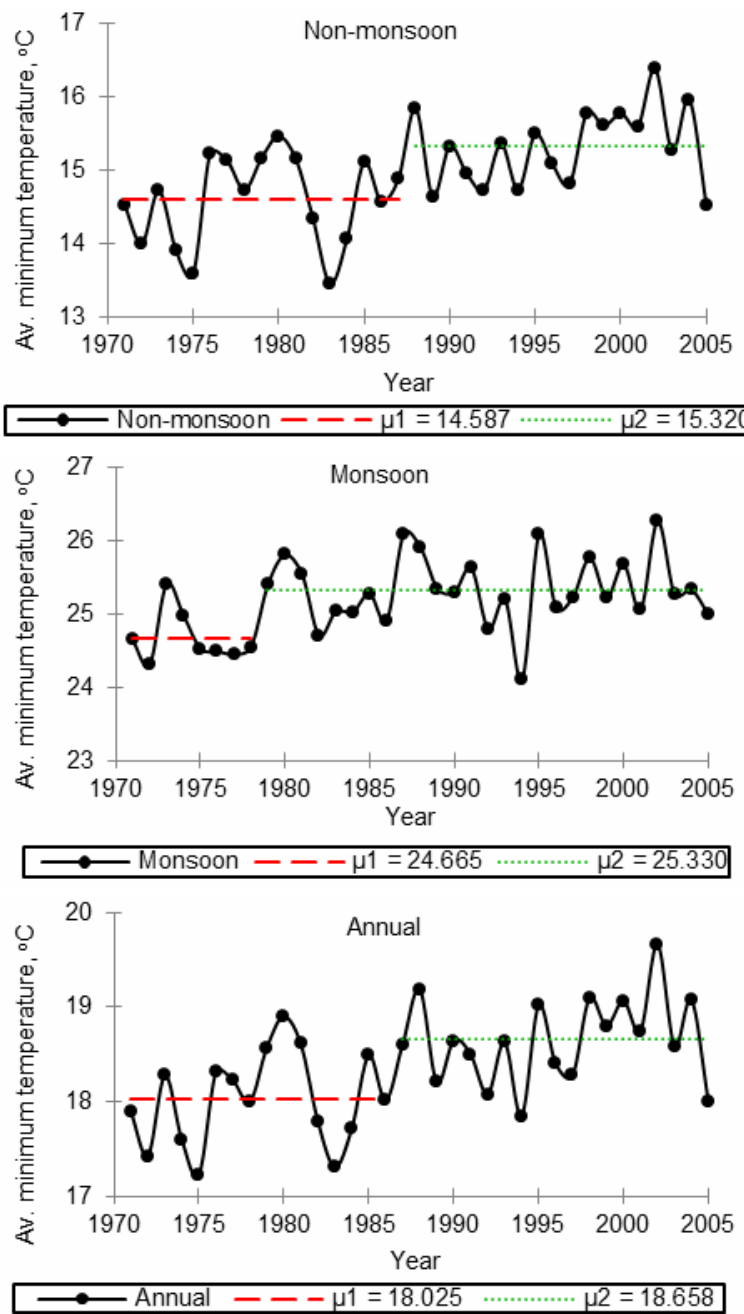

Fig. 11. Shift detection in average minimum temperature in Ajmer district; source: own study
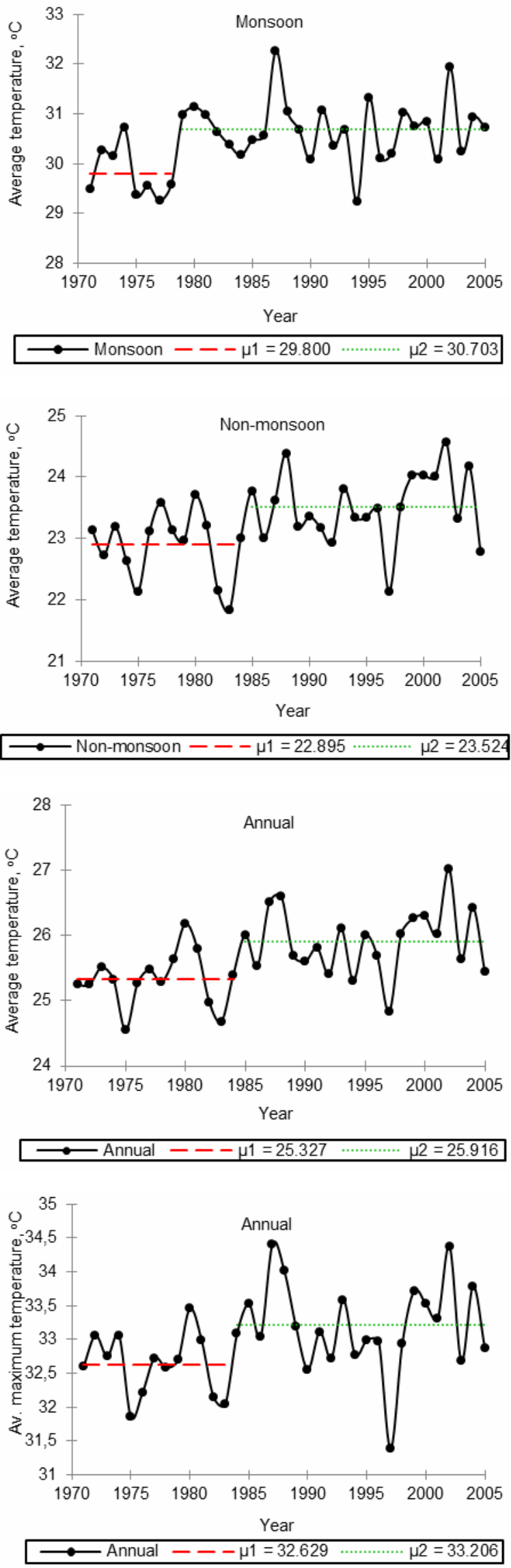

Fig. 12. Shift detection in average and maximum temperature in Ajmer district; source: own study 

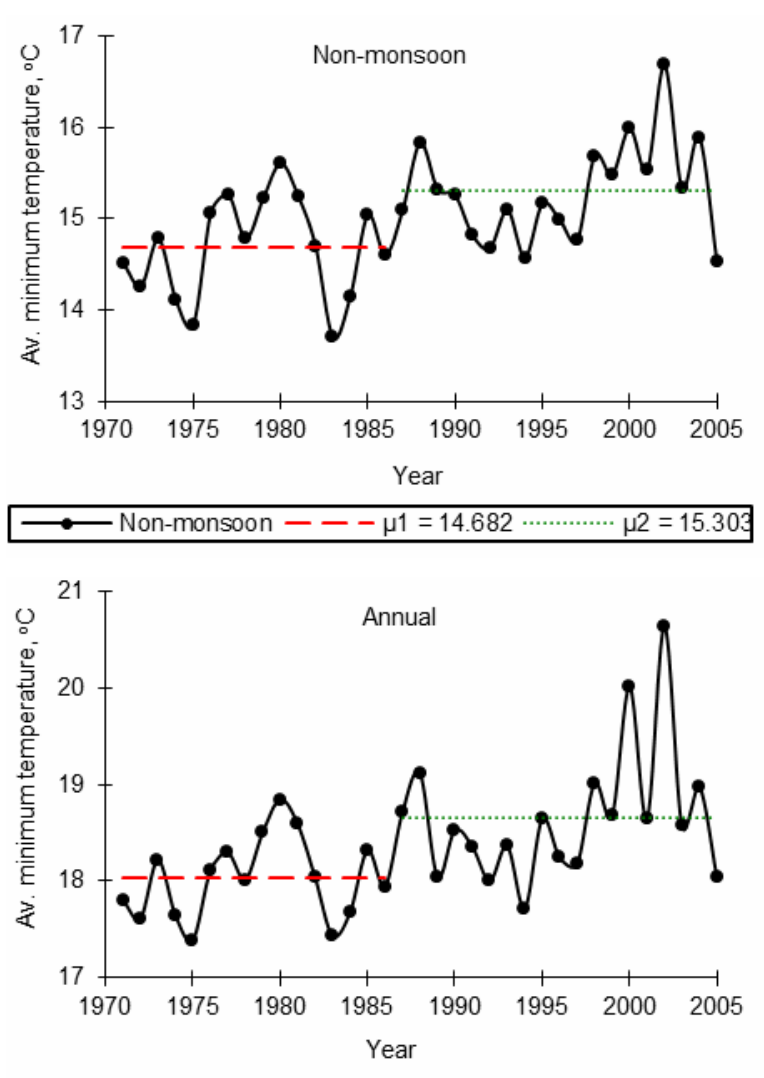

\begin{tabular}{|l|l|}
\hline$\longrightarrow$ Annual $\quad---\mu 1=18.028$ & $\cdots \cdots \cdots \cdots \cdots$
\end{tabular}

Fig. 13. Shift detection in average minimum temperature in Rajasthan State; source: own study annual average maximum temperature was observed during 1983-1984 in Ajmer city and Ajmer district (Tab. 4). Positive shifts in minimum, average, and maximum temperature were observed at these spatial scales. The changes in climate are likely due to the global climate shift or weakening global monsoon circulation, reduction in forest cover, and increasing aerosol due to anthropogenic activities [BASISTHA et al. 2009]. The increase in temperature may be due to the intensification of the hydrologic cycle in the urban area, which affects the spatial distribution of rainfall.

\section{STATISTICAL CHARACTERISTICS AT DIFFERENT SPATIAL SCALES}

The mean, standard deviation, kurtosis, coefficient of skewness, and coefficient of variation $C V$ of the rainfall and temperature series are presented in Table 5 for Ajmer city, Ajmer district and Rajasthan State. These statistical measures also confirm the variations in annual and seasonal (monsoon and nonmonsoon) average rainfall and temperature (Figs. 14 to 17$)$. The low value of kurtosis $(-0.85)$ that indicates smaller peaks in the average annual rainfall (19712005) at Rajasthan State, is driven by the lower number of rainfall events with similar intensity. The variability in rainfall events was very high and formed significant peaks in the monsoon and non-monsoon season (Tab. 5). However, non-monsoon average rainfall in Ajmer city and Ajmer district, higher values of

Table 5. Statistical characteristics of climatic variables for different spatial scales.

\begin{tabular}{|c|c|c|c|c|c|c|c|c|c|c|c|c|c|c|c|}
\hline \multirow{3}{*}{ Season } & \multicolumn{15}{|c|}{ Variable } \\
\hline & \multicolumn{3}{|c|}{ mean } & \multicolumn{3}{|c|}{ STD } & \multicolumn{3}{|c|}{ KURT } & \multicolumn{3}{|c|}{ SKEW } & \multicolumn{3}{|c|}{$\mathrm{CV}$} \\
\hline & AJC & AJD & RJ & $\mathrm{AJC}$ & AJD & RJ & AJC & AJD & RJ & AJC & AJD & RJ & AJC & AJD & $\mathrm{RJ}$ \\
\hline \multicolumn{16}{|c|}{ Rainfall } \\
\hline Annual & 481.62 & 480.58 & 440.11 & 200.66 & 167.98 & 113.75 & -0.23 & 0.24 & -0.85 & 0.25 & 0.65 & 0.13 & 41.66 & 34.95 & 25.85 \\
\hline Monsoon season & 443.94 & 434.47 & 389.28 & 181.13 & 152.71 & 112.64 & -0.24 & 0.33 & -0.65 & 0.12 & 0.63 & 0.25 & 40.80 & 35.15 & 28.94 \\
\hline $\begin{array}{l}\text { Non-monsoon } \\
\text { season }\end{array}$ & 37.68 & 44.32 & 49.32 & 44.67 & 38.11 & 30.04 & 9.04 & 9.65 & 1.97 & 2.79 & 2.55 & 1.26 & 118.54 & 85.98 & 60.91 \\
\hline \multicolumn{16}{|c|}{ Minimum temperature } \\
\hline Annual & 18.46 & 18.37 & 18.30 & 0.62 & 0.57 & 0.49 & -0.14 & -0.28 & -0.49 & -0.29 & -0.05 & 0.08 & 3.34 & 3.10 & 2.67 \\
\hline Monsoon season & 25.03 & 25.18 & 24.96 & 0.56 & 0.53 & 0.46 & -0.46 & -0.41 & -0.30 & -0.03 & 0.06 & 0.12 & 2.25 & 2.10 & 1.85 \\
\hline $\begin{array}{l}\text { Non-monsoon } \\
\text { season }\end{array}$ & 15.17 & 14.96 & 14.97 & 0.72 & 0.67 & 0.58 & 0.05 & -0.02 & -0.15 & -0.50 & -0.31 & -0.16 & 4.77 & 4.48 & 3.84 \\
\hline \multicolumn{16}{|c|}{ Average temperature } \\
\hline Annual & \begin{tabular}{|l|}
25.63 \\
\end{tabular} & 25.68 & 25.45 & 0.58 & 0.55 & 0.48 & 0.04 & 0.06 & 0.07 & 0.11 & 0.20 & 0.25 & 2.25 & 2.15 & 1.89 \\
\hline Monsoon season & 30.21 & 30.50 & \begin{tabular}{|l|}
30.17 \\
\end{tabular} & 0.71 & 0.69 & 0.65 & 0.39 & 0.43 & 0.39 & 0.13 & 0.20 & 0.36 & 2.35 & 2.28 & 2.16 \\
\hline $\begin{array}{l}\text { Non-monsoon } \\
\text { season }\end{array}$ & 23.34 & 23.27 & 23.08 & 0.67 & 0.64 & 0.56 & 0.19 & 0.09 & 0.35 & -0.31 & -0.25 & -0.17 & 2.85 & 2.74 & 2.41 \\
\hline \multicolumn{16}{|c|}{ Maximum temperature } \\
\hline Annual & 32.80 & 32.99 & 32.60 & 0.67 & 0.65 & 0.58 & 0.71 & 0.58 & 0.95 & -0.05 & 0.02 & -0.07 & 2.03 & 1.98 & 1.77 \\
\hline Monsoon season & 35.39 & 35.82 & 35.35 & 0.99 & 0.97 & 0.89 & 0.28 & 0.38 & 0.62 & 0.14 & 0.21 & 0.40 & 2.80 & 2.72 & 2.51 \\
\hline $\begin{array}{l}\text { Non-monsoon } \\
\text { season }\end{array}$ & 31.51 & 31.58 & 31.22 & 0.78 & 0.77 & 0.70 & 1.06 & 0.66 & 0.97 & -0.78 & -0.69 & -0.81 & 2.49 & 2.45 & 2.25 \\
\hline
\end{tabular}

Explanations: AJC = Ajmer city, AJD = Ajmer district, RJ = Rajasthan State, $S T D=$ standard deviation, $K U R T=$ kurtosis, $S K E W=$ coefficient of skewness, $C V=$ coefficient of variation.

Source: own study. 

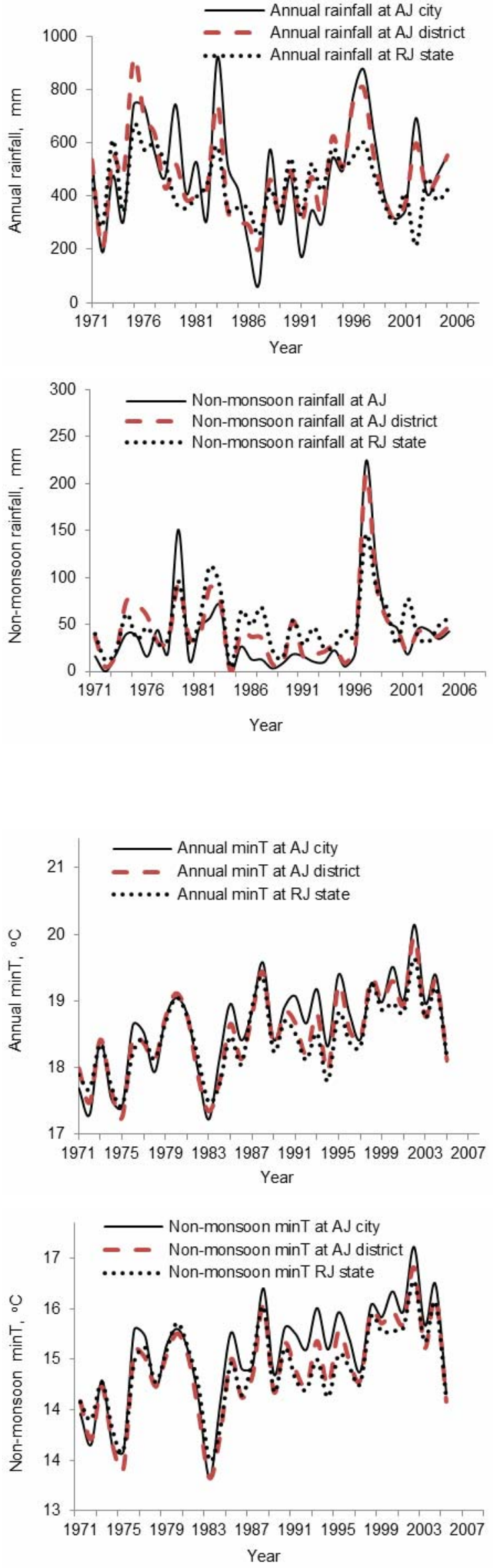

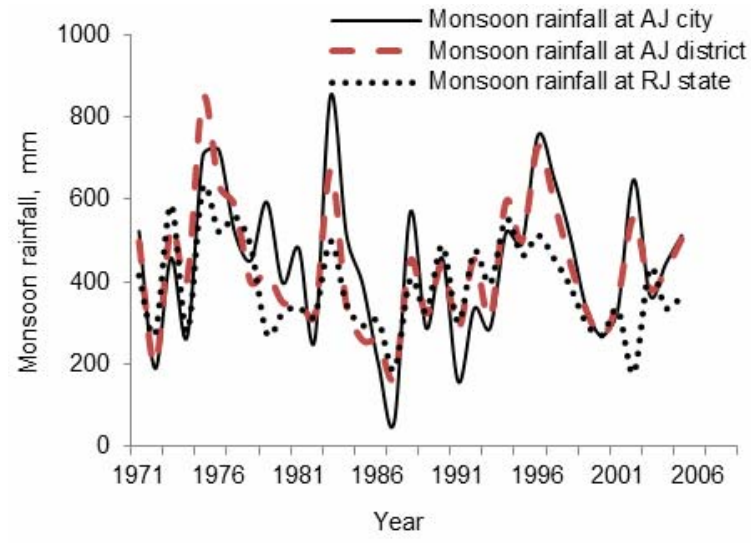

Fig. 14. Comparison of annual and seasonal rainfall variation in Ajmer city (AJ city), Ajmer district (AJ district) and Rajasthan State (RJ state); source: own study

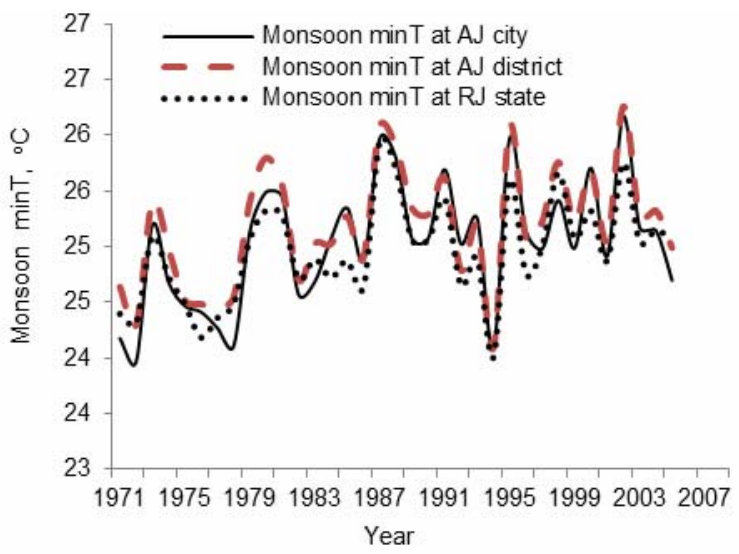

Fig. 15. Comparison of annual and seasonal minimum temperature (minT) variation in Ajmer city (AJ city), Ajmer district (AJ district) and Rajasthan State (RJ state); source: own study 

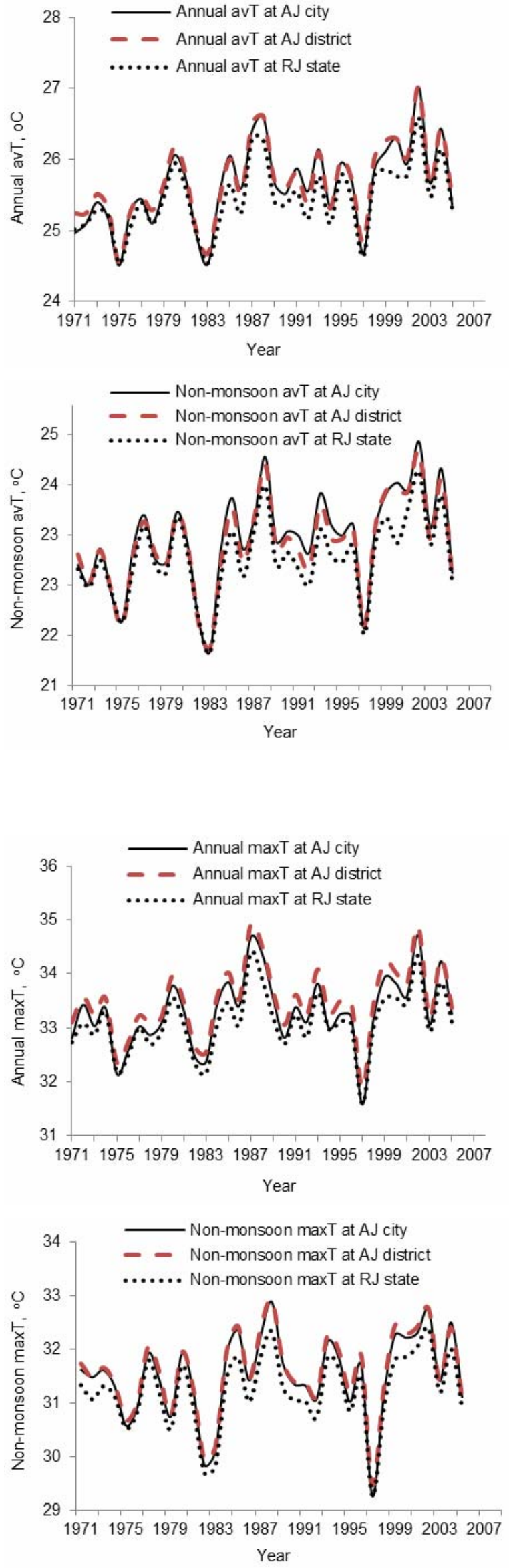

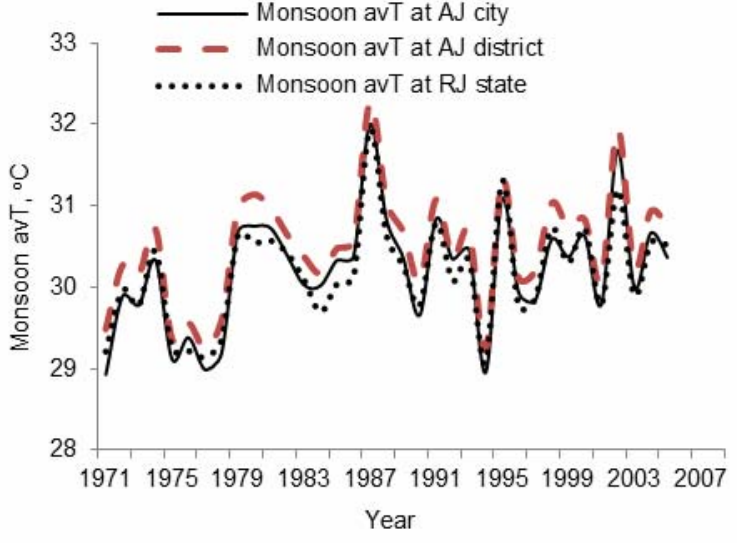

Fig. 16. Comparison of annual and seasonal average temperature (avT) variation in Ajmer city (AJ city), Ajmer district (AJ district) and Rajasthan State (RJ state); source: own study

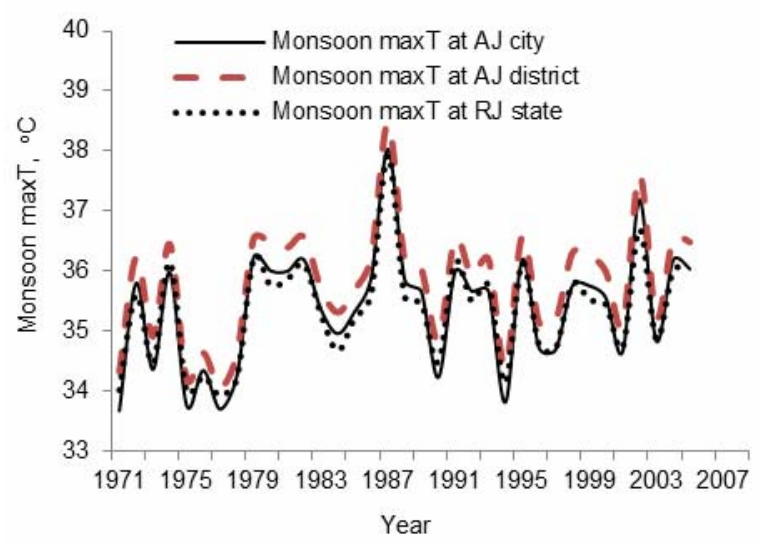

Fig. 17. Comparison of non-monsoon maximum temperature $(\operatorname{maxT})$ variation in Ajmer city (AJ city), Ajmer district (AJ district) and Rajasthan State (RJ state); source: own study 
kurtosis (i.e. 9.04 and 9.65, respectively) were observed than in Rajasthan State. The monsoon season average minimum temperature had a low value $(-0.46)$ of kurtosis for Ajmer city. However, a high value $(0.05)$ of kurtosis was observed for minimum temperature for the non-monsoon season at a local scale (Ajmer city). Average and average maximum temperature in annual and monsoon season showed low values of kurtosis (i.e. 0.04 and 0.28 , respectively) in Ajmer city. Average and average maximum temperature in non-monsoon and monsoon seasons showed a maximum value of kurtosis (i.e. 1.06 and 0.43 , respectively) in Ajmer city and Ajmer district (Tab. 5).

The statistical analysis indicates that seasonal (monsoon and non-monsoon) and annual average rainfall show maximum variability $(40.80 \%, 118.54 \%$ and $41.66 \%$, respectively) in Ajmer city rather than in Ajmer district and Rajasthan State. However, maximum variability in average rainfall was observed during the non-monsoon season in Ajmer city (Tab. 5). Low and high variation in rainfall makes the region highly vulnerable to climate change [KUMAR et al. 2010]. Maximum variability (4.77\%) was observed in average minimum temperature during the non-monsoon season in Ajmer city compared to Ajmer district and Rajasthan State. The maximum variability in nonmonsoon season and annual minimum temperature was observed in Rajasthan State. Seasonal and annual average and maximum temperature had maximum variability in Ajmer city compared to Ajmer district and Rajasthan State (Tab. 5). This may be due to changing land use/land cover and several other local anthropogenic activities, which are generalized at a coarser scale. The impacts of temperature change have different effects at global, regional and local scales. Therefore, information on such change is required to plan the short and long term development goals and adaptation strategies in a changing climate at different spatial scales [JEGANATHAN, ANDIMUTHA 2013].

\section{SUMMARY AND CONCLUSIONS}

Spatial and temporal scale plays an important role at global, regional and local levels. In the present study, trends and shift analysis of annual and seasonal rainfall and temperature were performed for the period of 1971-2005 at different spatial scales (Ajmer city, Ajmer district and Rajasthan State). These were carried out using the MK test, MMK test, MK-PW test, and the PMW test at these scales. The trend test results suggest that average and average minimum temperature (i.e. monsoon, non-monsoon season and annual) had an increasing trend at a $10 \%$ significance level at all three spatial scales. It was observed that annual average minimum temperature increased at the rate of $0.037^{\circ} \mathrm{C}, 0.032^{\circ} \mathrm{C}$ and $0.028^{\circ} \mathrm{C}$ in Ajmer city, Ajmer district and Rajasthan State, respectively. Average minimum temperature has increased at the rate of $0.026^{\circ} \mathrm{C}, 0.021^{\circ} \mathrm{C}$ and $0.023^{\circ} \mathrm{C}$ in the monsoon season, and at the rate of $0.043^{\circ} \mathrm{C}, 0.038^{\circ} \mathrm{C}$ and $0.031^{\circ} \mathrm{C}$ in the non-monsoon season, respectively. Similarly, average temperature increased at the rate of $0.030^{\circ} \mathrm{C}, 0.028^{\circ} \mathrm{C}$ and $0.021^{\circ} \mathrm{C} ; 0.023^{\circ} \mathrm{C}, 0.219^{\circ} \mathrm{C}$ and $0.022^{\circ} \mathrm{C}$; and $0.30^{\circ} \mathrm{C}, 0.029^{\circ} \mathrm{C}$ and $0.021^{\circ} \mathrm{C}$ during the annual, monsoon and non-monsoon seasons, respectively at the three spatial scales. Increasing trends were observed in annual average maximum temperature at the rate of $0.022^{\circ} \mathrm{C}, 0.021^{\circ} \mathrm{C}$ and $0.020^{\circ} \mathrm{C}$ at the three spatial scales. Thus, the results of annual and seasonal average temperature (annual: $0.037^{\circ} \mathrm{C}>$ $0.032^{\circ} \mathrm{C}>0.028^{\circ} \mathrm{C}$; non-monsoon season: $0.043^{\circ} \mathrm{C}>$ $0.038^{\circ} \mathrm{C}>0.031^{\circ} \mathrm{C}$ ) were shown to have significant changes in Ajmer city compared to Ajmer district and Rajasthan State. This indicates that climate change effects are more pronounced at local scales (urban) compared to regional and global scales. It was also observed that annual and seasonal average rainfall did not have any significant trend.

The PMW test revealed that significant shifts were observed only in non-monsoon season rainfall, which had an increase in rainfall after 1995 in Ajmer city. However, test results indicate that significant shifts in rainfall were not observed in Ajmer district and Rajasthan State. In the case of annual and seasonal minimum, average and maximum temperature, positive significant shifts were observed at these three scales except a few spatial and temporal scales. The statistical analysis indicates that seasonal and annual average rainfall has a maximum variability $(40.80 \%$, $118.54 \%$ and $41.66 \%$, respectively) in Ajmer city compared to Ajmer district and Rajasthan State.

This paper has provided results on the assessment of climate change at different spatial scales in the arid and semi-arid region of Rajasthan State in India. The inverse approach (local to global) was applied in the present study to ascertain the implications of spatial scale on climate change assessment. The detailed discussion regarding different spatial and temporal scales confirmed that climate change effects are more pronounced at the urban city scale compared to State scale. This may due to changes in land use/land cover change (LULC) and anthropogenic activities such as urbanization, industrialization, pollution, and deforestation, among others. In light of this, assessments of climate change are necessary at finer spatial resolutions for optimal adaptation and mitigation measures. Further, future studies could focus on the future scenarios of climate change and predictive uncertainties using multiple global climate models (GCMs) at different spatial and temporal scales. The LULC change, population growth, concentration of gases and other causative factors could also be considered to assess the climate change at local scale.

\section{Acknowledgements}

We gratefully acknowledge the Indian Metrological Department (IMD) in Pune for providing the meteorological gridded data datasets for this research. Financial assistance provided by the Ministry of Human Resource Development 
of the Government of India in the form of a scholarship is acknowledged. Partial funding for this research was also provided by an NSERC Discovery and CFI grant held by Jan Adamowski.

\section{REFERENCES}

ADAMOWSKI J., ADAMOWSKI K., BOUgadis J. 2010. Influence of trend on short duration design storms. Water Resources Management. Vol. 24. Iss. 3 p. 401-413.

Adamowski J., Chan H., Prasher S., Sharda V.N. 2012a. Comparison of multivariate adaptive regression splines with coupled wavelet transform artificial neural networks for runoff forecasting in Himalayan microwatersheds with limited data. Journal of Hydroinformatics. Vol. 14. Iss. 3 p. 731-744.

ADAMOWSKI J., PROKOPH A. 2013. Assessing the impacts of the urban heat island effect on streamflow patterns in Ottawa, Canada. Journal of Hydrology. Vol. 496 p. 225-237.

Adamowski K., Prokoph A., Adamowski J. 2009. Development of a new method of wavelet aided trend detection and estimation. Hydrological Processes. Vol. 23 p. 2686-2696.

Adamowski K., Prokoph A., Adamowski J. 2012b. Influence of the 11 year solar cycle on annual streamflow maxima in Canada. Journal of Hydrology. Vol. 442-443 p. 55-62.

Araghi A., Adamowski J., Nalley D., Malard J. 2015. Using wavelet transforms to estimate surface temperature trends and dominant periodicities in Iran based on gridded reanalysis data. Journal of Atmospheric Research. Vol. 155 p. 52-72.

Arora M., Goel N.K., Singh P. 2005. Evaluation of temperature trends over India. Hydrological Sciences Journal. Vol. 50. Iss. 1 p. 81-93.

Basistha A., ARYa D.S., Goel N.K. 2009. Analysis of historical changes in rainfall in the Indian Himalayas. International Journal of Climatology. Vol. 29. Iss. 4 p. 555-572.

Basistha A., Goel N.K., ARYa D.S., Gangwar S.K. 2007. Spatial pattern of trends in Indian sub-divisional rainfall. Jalvigyan Sameeksha. Vol. 22 p. 47-57.

BLÖSCHL G. 1999. Scaling issues in snow hydrology. Hydrological Processes. Vol. 13. Iss. 1415 p. 2149-2175.

BlÖSChl G., SivaPAlan M. 1995. Scale issues in hydrological modelling: a review. Special issue: Scale issues in hydrological modelling. Hydrological Processes. Vol. 9. Iss. 3-4 p. 251-290.

BormanN H., DieKkrüger B., RenSChler C. 1999. Regionalization concept for hydrological modeling on different scales using a physically based model: results and evaluation. Physics and Chemistry of the Earth. Part B: Hydrology, Oceans and Atmosphere. Vol. 24. Iss. 7 p. 799-804.

BuRn D.H., ELnUR M.A. 2002. Detection of hydrologic trends and variability. Journal of Hydrology. Vol. 255. Iss. 1 p. 107-122.

CAMPISI S., ADAmOWSKi J., ORON G. 2012. Forecasting urban water demand via wavelet- denoising and neural network models. Case study: city of Syracuse, Italy. Water Resources Management. Vol. 26. Iss. 12 p. 35393558.

CARTWRIGHT I., SimMONDS I. 2008. Impact of changing climate and land use on the hydrogeology of southeast Australia. Australian Journal of Earth Sciences. Vol. 55. Iss. 8 p. 1009-1021.
Census of India 2011. Census Organization of India. Government of India.

Chung Y.S., Yoon M.B., Kim H.S. 2004. On climate variations and changes observed in South Korea. Climate Change. Vol. 66. Iss. 1-2 p. 151-161.

CUI L., SHI J. 2012. Urbanization and its environmental effects in Shanghai, China. Urban Climate. Vol. 2 p. 1-15.

CunderLiK J.M., BuRN D.H. 2004. Linkages between regional trends in monthly maximum flows and selected climatic variables. Journal of Hydrologic Engineering. Vol. 9. Iss. 4 p. 246-256.

Das P.K., Chakraborty A., Seshasai M.V.R. 2013. Spatial analysis of temporal trend of rainfall and rainy days during the Indian Summer Monsoon season using daily gridded $0.5^{\circ} \times 0.5^{\circ}$. rainfall data for the period of $1971-$ 2005. Meteorological Applications. Vol. 21. Iss. 3. DOI: 10.1002/met.1361 p. 481-493.

Dash S.K., Jenamani R.K., KAlSi S.R., PANDA S.K. 2007. Some evidence of climate change in twentieth-century India. Climatic Change. Vol. 85. Iss. 3-4 p. 299-321.

DE U.S., RAO G.S.P. 2004. Urban climate trends - The Indian scenario. Journal of Indian Geophysical Union. Vol. 8. No. 3 p. 199-203.

EZBer Y.O., Sen L., KindaP T., KARACA M. 2007. Climatic effects of urbanization in Istanbul: a statistical and modeling analysis. International Journal of Climatology. Vol. 27. Iss. 5 p. 667-679.

Fischer T., GeMmer M., LiU L., Su B. 2012. Change-points in climate extremes in the Zhujiang River Basin, South China, 1961-2007. Climatic Change. Vol. 110. Iss. 3-4 p. 783-799.

FUJIBE F. 1995. Temperature rising trends at Japanese cities during the last hundred years and their relationships with population, population increasing rates and daily temperature ranges. Meteorology and Geophysics. Vol. 46. Iss. 2 p. 35-55.

GAdGIL A., DHORDE A. 2005. Temperature trends in twentieth century at Pune. Atmospheric Environment. Vol. 39. Iss. 35 p. 6550-6556.

Gowda K.K., Majuantha K., Manjunath B.M., Putty Y.R. 2008. Study of climate changes at Davangere region by using climatological data. Water and Energy International. Vol. 65. Iss. 3 p. 66-77.

Haidary A., AmiRi B.J., AdAMOWSKi J., Fohrer N., NAKANE K. 2013. Assessing the impacts of four land use types on the water quality of wetlands in Japan. Water Resources Management. Vol. 27. Iss. 7 p. 2217-2229.

Halbe J., Pahl-Wostl C., Sendzimir J., Adamowski J. 2013. Towards adaptive and integrated management paradigms to meet the challenges of water governance. Water Science and Technology: Water Supply. Vol. 67 p. 2651-2660.

HAMED K.H., RAO A.R. 1998. A modified Mann-Kendall trend test for auto correlated data. Journal of Hydrology. Vol. 204. Iss. 1 p. 182-196.

HingANE L.S. 1995. Is a signature of socio-economic impact written on the climate? Climatic Change. Vol. 32. Iss. 1 p. $91-101$.

Huth R., Pokorna L. 2004. Parametric versus nonparametric estimates of climatic trends. Theoretical and Applied Climatology. Vol. 77. Iss. 1-2 p. 107-112.

IPCC 2007. AR4 Working group I report. The physical science basis. Cambridge. Cambridge Univ. Press. ISBN $978052188009-1$ pp. 966.

JAIN S.K., KUMAR V., SAHARIA M. 2013. Analysis of rainfall and temperature trends in northeast India. Interna- 
tional Journal of Climatology. Vol. 33. Iss. 4 p. 968 978.

Jeganathan A., Andimuthu R. 2013. Temperature trends of Chennai City, India. Theoretical and Applied Climatology. Vol. 111. Iss. 3 p. 417-425.

JHA R., PATRA K.C. 2009. Hydrological estimates of flow in ungauged sub-basin and impact of climate change in a typical river system of India. Joint International Convention of 8th IAHS Scientific Assembly and $37^{\text {th }}$ IAH Congress Water: A vital resource under stress - How science can help? September 6-12, 2009, Hyderabad, India.

JiAng F., Hu R., WANG S., Zhang Y., ToNG L. 2013. Trends of precipitation extremes during 1960-2008 in Xinjiang, the Northwest China. Theoretical and Applied Climatology. Vol. 111. Iss. 1 p. 133-148.

Karpouzos D.K., Kavalieratou S., Babajimopoulos C. 2010. Trend analysis of precipitation data in Pieria region Greece. European Water. Vol. 30 p. 31-40.

KenDALL M.G. 1975. Rank correlation methods. $4^{\text {th }}$ ed. London. Charles Griffin.

Kiely G., Albertson J.D., Parlange M.B. 1998. Recent trends in diurnal variation of precipitation at Valentia on the West Coast of Ireland. Journal of Hydrology. Vol. 207. Iss. 3-4 p. 270-279.

Kolinjivadi V., Adamowski J., Kosoy N. 2014. Recasting payments for ecosystem services (PES) in water resource management: A novel institutional approach. Ecosystem Services. Vol. 10 p. 144-154.

KolinjIVAdi V., GRANT A., AdAMOWSKi J., Kosoy N. 2015. Juggling multiple dimensions in a complex socio-ecosystem: The issue of targeting in payments for ecosystem services. GeoForum. Vol. 58 p. 1-13.

Kothawale D.R., Kumar R. 2005. On the recent changes in surface temperature trends over India. Geophysical Research Letters. Vol. 32. Iss. 18. L18714, DOI: 10.1029/2005GL023528.

KothyARI U.C., Singh V.P. 1996. Rainfall and temperature trends in India. Hydrological Processes. Vol. 10. Iss. 3 p. $357-372$.

KUMAR V., JAIN S.K., SingH Y. 2010. Analysis of long-term rainfall trends in India. Hydrological Sciences Journal. Vol. 55. Iss. 4 p. 484-496.

LiU Z., Xu Z., Charles S.P., Fu G., LiUA L. 2011. Evaluation of two statistical downscaling models for daily precipitation over an arid basin in China. International Journal of Climatology. Vol. 31. Iss. 13 p. 2006-2020.

Ludwig W., Serrat P., Cesmat L., Esteves J.G. 2004. Evaluating the impact of the recent temperature increase on the hydrology of the Têt River Southern France. Journal of Hydrology. Vol. 289 p. 204-221.

LuO Y., Lio S., Sheng L., Fu S., LiU J., WANG G., Zhou G. 2008. Trends of precipitation in Beijiang River Basin, Guangdong Province, China. Hydrological Processes. Vol. 22. Iss. 13 p. 2377-2386.

MANN H.B. 1945. Non-parametric test against trend. Econometrica. Vol. 13 p. 245-259.

MAtondo J.I., MsibI K.M. 2001. Estimation of the impact of climate change on hydrology and water resources in Swaziland. Water International. Vol. 26. Iss. 3 p. $425-$ 434.

McBean E., Motiee H. 2008. Assessment of impacts of climate change on water resources: a long term analysis of the Great Lakes of North America. Hydrology and Earth System Sciences. Vol. 12. Iss. 1 p. 239-255.

Mcavaney B., Covey C., Joussaume S., Kattsov V., Kitoh A., Ogana W., Pitman A., Weaver A., Wood R.,
ZhaO Z.C. 2001. Climate change 2001: The scientific basis. Chap. 8: Model evaluation. Contribution of Working Group I to the Third Assessment Report of the Intergovernmental Panel on Climate Change IPCC. Cambridge. Cambridge University Press p. 471-523.

ModARRES R., DA SILVA R.V.P. 2007. Rainfall trends in arid and semi-arid regions of Iran. Journal of Arid Environment. Vol. 70. Iss. 2 p. 344-355.

Motien H., McBean E. 2009. An assessment of long-term trends in hydrologic components and implications of water levels in Lake Superior. Hydrology Research Journal. Vol. 406 p. 564-579.

NALley D., ADAmowski J., Khalil B. 2012. Using discrete wavelet transforms to analyze trends in streamflow and precipitation in Quebec and Ontario 1954-2008. Journal of Hydrology. Vol. 475 p. 204-228.

Nalley D., Adamowski J., Khalil B., Ozga-Zielinski B. 2013. Trend detection in surface air temperature in Ontario and Quebec, Canada during 1967-2006 using the discrete wavelet transform. Journal of Atmospheric Research. Vol. 132-133 p. 375-398.

OKE T.R. 1987. Boundary layer climates. London, New York. Methuen. ISBN 0416044220 pp. 435.

Pant G.B., Kumar K.R. 1997. Climates of South Asia. Chichester. John Wiley \& Sons Ltd. ISBN 0471949485 pp. 320.

Patra J.P., Mishra A., Singh R., Raghuwanshi N.S. 2012. Detecting rainfall trends in twentieth century (18712006) over Orissa State, India. Climatic Change. Vol. 111. Iss. 3-4 p. 801-817. DOI $10.1007 / \mathrm{s} 10584-011-$ 0215-5

Pingale S., Khare D., Jat M., Adamowski J. 2014. Spatial and temporal trends of mean and extreme rainfall and temperature for the 33 urban centres of the arid and semi-arid state of Rajasthan, India. Journal of Atmospheric Research. Vol. 138 p. 73-90.

RAI R.K., UPADHYAY A., OJHA C.S.P. 2010. Temporal variability of climatic parameters of Yamuna River Basin: spatial analysis of persistence, trend and periodicity. The Open Hydrology Journal. Vol. 4. Iss. 1 p. 184-210.

RAO A.R., HAMED K.H., CHEN H.L. 2003. Nonstationarities in hydrologic and environmental time series. Kluwer Academic Publishers: The Netherlands pp. 362.

RATHOR M.S. 2005. State level analysis of drought policies and impacts in Rajasthan, India. Colombo, Sri Lanka: IWMI. 40p. Working paper 93: Drought Series Paper 6. ISBN 929090593X pp. 29.

RENSCHLER C.S. 2003. Designing geo-spatial interfaces to scale process models: The GeoWEPP approach. Hydrological Processes. Vol. 17. Iss. 5 p. 1005-1017.

RENSCHLER C.S. 2005. Scales and uncertainties in volcano hazard prediction-optimizing the use of GIS and models. Journal of Volcanology and Geothermal Research. Vol. 139. Iss. 1-2 p. 73-87.

SAAdat H., AdAmowski J., Bonnell R., Sharifi F., NAMDAR M., Ale-Ebrahim S. 2011. Land use and land cover classification over a large area in Iran based on single date analysis of satellite imagery. Journal of Photogrammetry and Remote Sensing. Vol. 66. Iss. 5 p. 608-619.

Saboohi R., Soltani S., Khodagholi M. 2012. Trend analysis of temperature parameters in Iran. Theoretical and Applied Climatology. Vol. 109. Iss. 3 p. 529-547.

SCHUBERT S. 1998. Downscaling local extreme temperature changes in south-eastern Australia from the CSIRO Mark2 GCM. International Journal of Climatology. Vol. 18. Iss. 13 p. 1419-1438. 
SEN P.K. 1968. Estimates of the regression coefficient based on Kendall's tau. Journal of the American Statistical Association. Vol. 63. Iss. 324 p. 1379-1389.

Stathopoulou M., Cartalis C. 2007. Daytime urban heat islands from Landsat ETM+ and Corine land cover data: An application to major cities in Greece. Solar Energy. Vol. 81. Iss. 3 p. $358-368$.

Straith D., AdAmOwSKi J., ReILly K. 2014. Exploring the behavioural attributes, strategies and contextual knowledge of champions of change in the Canadian water sector. Canadian Water Resources Journal. Vol. 39. Iss. 3 p. $255-269$.

THEIL H. 1950. A rank-invariant method of linear and polynomial regression analysis. I, II, III. Nedal. Akad. Wetensch. Proc. 53 p. 386-392.

TIWARI M., ADAMOWSKI J. 2013. Urban water demand forecasting and uncertainty assessment using ensemble wavelet-bootstrap-neural network models. Water Resources Research. Vol. 49. Iss. 10 p. 6486-6507.

Tozer C.R., Kiem A.S., Verdon-KidD D.C. 2012. On the uncertainties associated with using gridded rainfall data as a proxy for observed. Hydrology and Earth System Sciences. Vol. 16. Iss. 5 p. 1481-1499.

Wagesho N., Goel N.K., Jain M.K. 2013. Temporal and spatial variability of annual and seasonal rainfall over Ethiopia. Hydrological Sciences Journal. Vol. 58. Iss. 2 p. 354-373.

YoON W.S., LEE D.K. 2003. The development of the evaluation model of climate changes and air pollution for sustainability of cities in Korea. Landscape and Urban Planning. Vol. 63. Iss. 3 p. 145-160.

YUE S., HASHINO M. 2003. Long term trends of annual and monthly precipitation in Japan. Journal of the American Water Resources Association. Vol. 39. Iss. 3 p. 587 596.

Yue S., Pilon P. 2004. A comparison of the power of the $t$ test, Mann-Kendall and bootstrap tests for trend detection. Hydrological Sciences Journal. Vol. 491. Iss. 1 p. 21-37.

Zhang X.B., Zwiers F.W., Li G.L. 2004. Monte Carlo experiments on the direction of trends in extreme values. Journal of Climate. Vol. 17. Iss. 10 p. 1945-1952.

\section{Santosh PINGALE, Jan ADAMOWSKI, Mahesh JAT, Deepak KHARE}

\section{Konsekwencje różnej skali przestrzennej w ocenach zmian klimatu}

\section{STRESZCZENIE}

Słowa kluczowe: analiza trendu, analiza zmian, efekt skali, Indie, stan Rajasthan, zmiany klimatu

W szacowaniu skutków zmian klimatu w skali globalnej lub regionalnej czynniki lokalne warunkujące zmiany klimatu są uogólniane, co skutkuje uśrednianiem efektów. Zmiany klimatu powinny jednak być oceniane w skali mikro, aby ustalić ich natężenie. W celu określenia wpływu skali przestrzennej na oceny zmian klimatycznych oznaczono roczne i sezonowe (pora monsunowa i pozamonsunowa) trendy temperatury i opadów (minimalne, średnie, maksymalne) w trojakiej rozdzielczości: dla miasta Ajmer, dystryktu Ajmer i stanu Rajasthan w Indiach. W analizie trendu wykorzystano test Manna-Kendalla (MK), test MK z wstępnym wygładzaniem (MK-KW), zmodyfikowany test Manna-Kendalla (MMK) i inne techniki statystyczne. Do wykrycia czasowych zmian parametrów klimatycznych użyto testu Pettitta-Manna-Whitneya (PMW). Dla okresu badawczego (35 lat) określono także nachylenie Sena i zmiany opadów i temperatury (w \%). Średnie roczne i sezonowe wartości temperatury wskazywały istotną tendencję do ocieplania klimatu, kiedy oceny dokonywano w skali miasta, niż gdy analizie poddawano obszary o większej skali przestrzennej (dystrykt Ajmer i stan Rajasthan). Zaobserwowano rosnące trendy dla minimalnej, średniej i maksymalnej temperatury we wszystkich skalach przestrzennych, jednak silniej przejawiały się one w mniejszej skali (miasto Ajmer). Test PMW wykazał istotną zmianę jedynie w wielkości opadów w sezonie pozamonsunowym - wzrost opadów po 1995 r. w mieście Ajmer. Kurtoza i współczynnik zmienności wykazały także istotne zmiany klimatyczne, kiedy rozpatrywano je w mniejszej skali (miasto Ajmer). Takiej prawidłowości nie zaobserwowano w skali regionalnej. Wyniki świadczą o wpływie zmian w użytkowaniu/pokryciu terenu i innych czynników antropogenicznych na zmiany klimatu. Z tego powodu mogą one być użyteczne w opracowaniu optymalnych strategii adaptacji i łagodzenia skutków zmian klimatycznych na podstawie ich intensywności w różnych skalach przestrzennych. 